\title{
A FLORA DE EPÍFITAS VASCULARES DA RESERVA DA CIDADE UNIVERSITÁRIA "ARMANDO DE SALLES OLIVEIRA" (SÃO PAULO, BRASIL)
}

\author{
RICARDO DISLICH \& WALDIR MANTOVANI
}

\author{
Departamento de Ecologia Geral, Instituto de Biociências, Universidade de São Paulo. Cx. Postal 11461, 05422-970 - São Paulo, SP, Brasil.
}

\begin{abstract}
The vascular epiphyte flora of the Reserve of the Cidade Universitária "Armando de Salles Oliveira", São Paulo, Brazil). This work is a survey of the epiphytes of the Reserve of the Cidade Universitária "Armando de Salles Oliveira", in São Paulo, SP (Brazil), here defined as vascular plants usually found living on others, without parasitizing them, during at least a part of their life cycles. The study site (approximately $46^{\prime \prime} 43^{\prime} \mathrm{W}, 23^{\prime \prime} 33^{\prime} \mathrm{S}$ ) is a secondary forested area isolated in urban environment and represents one of the few forested areas in this city. The climate type is Köppen's Cwa, and the mean annual precipitation is $1207 \mathrm{~mm}$. Polypodiaceae (9 species), Bromeliaceae (8), Orchidaceae (6), Moraceae (4), Araceae (4), Cactaceae (3), Piperaceae (1), Blechnaceae (1) and Araliaceae (1) are the families of epiphytes found at the study site, making up 37 species belonging to 20 gencra. Three of them are exotic: Schefflera actinophylla (Araliaceae), Ficus microcarpa (Moraceae) and Philodendron er'ubescens (Araceae). Families, genera and species descriptions are provided, as well as an identification key to the species based exclusively on vegetative characters, identification keys to species and genera in each family and comments on the phenology, geographic distribution and ecology of the species. Most of them show widespread geographic distribution. All main epiphytic life forms are represented.
\end{abstract}

\begin{abstract}
Resumo - (A flora de epífitas vasculares da Reserva da Cidade Universitária "Armando de Salles Oliveira", São Paulo, Brasil). Estc trabalho trata do levantamento das espécies de epífitas da Reserva da Cidade Universitária "Armando de Salles Oliveira", em São Paulo, SP, aqui consideradas como plantas vasculares usualmente encontradas sobre outras, sem parasitá-las, durante alguma fase do ciclo de vida. O local de estudos (aproximadamente 46"43' W, 23'33’S) é uma ilha de mata secundária em ambiente urbano e representa uma das poucas áreas cobertas por floresta na região, tendo pouco mais de 10 ha. O clima é do tipo Cwa de Köppen, com precipitação média anual de $1207 \mathrm{~mm}$. As famílias de epífitas representadas são Polypodiaceae (9 espécies), Bromeliaceae (8), Orchidaceae (6), Moraceac (4), Araceae (4), Cactaceae (3), Piperaceae (1), Blechnaceae (1) e Araliaceae (1), totalizando 37 espécies pertencentes a 20 gêneros. Tiês delas são exóticas: Schefflera actinophylla (Araliaceae), Ficus microcarpa (Moraceae) e Philodendron crubescens (Araceae). São apresentadas descrições das famílias, gêneros e espécies; uma chave para iclentificação das espécies baseada exclusivamente em caracteres vegetativos; chaves de identificação para os gêneros e espécies de cada família, assim como comentários sobre a fenologia, distribuição geográfica e ecologia das espécies. A maioria delas apresenta ampla distribuição geográfica. Estão representadas todas as principais formas de vida epifíticas conhecidas.
\end{abstract}

Key words: vascular epiphytes, floristics, fragmented forest.

\section{Introdução}

O conhecimento acerca dos remanescentes da cobertura vegetal da cidade de São Paulo é restrito a alguns trabalhos florísticos e fitossociológicos, isolados (Usteri 1906, 1911, de Vuono 1985, Gomes 1992, Gorresio-Roizman 1993, Rossi 1994, Tabarelli 1994, Knobel 1995, Garcia 1995) ou sob a forma de projetos mais amplos (Melhem et al. 1981). Não existe um único fragmento florestal na cidade que possua uma lista completa das suas espécies de plantas vasculares.

Este trabalho faz uma contribuição ao conhecimento florístico de um desses fragmentos, através do estudo do grupo de plantas vasculares que são usualmente cncontradas, durante alguma fase da vida, sobre outras plantas, sem, porém, parasitá-las, tratadas aqui sob a denominação comum de epífitas. Este componente vegetacional tem importância considerável em florestas tropicais, tanto do ponto de vista fisionômico quanto florístico, podendo chegar a representar $35 \%$ do número de espécies de plantas vasculares, em locais de grande pluviosidade (Gentry \& Dodson 1987b). As epífitas também influem nos processos de ciclagem de água e de nutrientes na floresta e na sua produtividade (Hofstede et al. 1993) e são fontes de recursos importantes para a fauna nesses ambientes (Nadkarni 1988, Benzing 1995).

As epífitas vasculares no Brasil raramente receberam atenção especial do ponto de vista florístico. Hertel (1950), estudando estas plantas em matas na vertente oeste da Serra do Mar, próximo a Curitiba, identificou 98 espécies de 12 famílias. Aguiar et al. (1981) encon- 
traram 17 espécies de 4 famílias em uma área em Montenegro (RS) e Triun fo (RS), sobre 37 árvores examinadas. Wacchter (1986) fez o levantamento florístico das epílitas vasculares de uma mata paludosa em Torres (RS), encontrando 120 espécies pertencentes a 55 gêneros c 15 famílias. Cervi et al. (1988) fizeram um levantamento florístico de epífitas vasculares, com exceção das Bromeliaceae, em área de 13,9 ha de floresta de araucária na região urbana de Curitiba, tendo encontrado 26 espécies de 15 gêneros e 6 famílias. Waechter (1992) estudou as epífitas vasculares da Planície Costeira do Rio Grande do Sul, adotando uma abordagem mais ampla, fitogeográfica. Encontrou 250 espécies distribuídas cm 27 famílias c 102 gêneros e um gradiente decrescente de riqueza de espécies em direçĩo ao sul. Orchidaceae é, via de regra, a família com matior riqueza específica. Bromeliaceae c Pteridophyta também são importantes, neste contexto.

Este trabalho tem como objetivos contribuir para o conhecimento da flora epifítica da floresta ombrófila clensa e tornar possível o reconhecimento das espécies de cpífitas vasculares presentes no local de estudos.

\section{Material e Métodos}

Local de Estudo - A Cidade Universitária "Armando de Salles Oliveira" (CUASO), da Universidade de São P'aulo (USP), localiza-se no bairro do Butantã, em São Paulo, SP. Em scu interior, próxima às coordenadas geográlicas $46^{\circ} 43^{\prime} \mathrm{W}$ e $23^{\prime \prime} 33^{\prime} \mathrm{S}$, localiza-se a reserva estuclada neste trabalho, com uma área de $102.100 \mathrm{~m}^{2}$, siluada no vale de $\mathrm{um}$ riacho, que se estende na direção $\mathrm{S}-\mathrm{N}$, cm terreno com desnível de 30 metros entre as partes mais altas, a $765 \mathrm{~m}$, e as mais baixas, a $735 \mathrm{~m}$, onde há um pequeno lago formado por represa. Rossi (1994) apresentou um mapa da Reserva.

A árca situa-se na bacia de São Paulo, caracterizada por clepósitos do Terciário e do Quaternário (Joly 1950). O solo é essencialmente argiloso, ácido, pobre cm nutrientes, com altos teores de alumínio e capacidade de campo de 40,4g / 100ml de solo (Varanda 1977).

A média de umidade relativa do ar fica ao redor de $80 \%$. Durante todo o ano predominam os ventos de origem marítima, de direção SE (Varanda 1977). O clima é do tipo Cwa, de Köppen (1948), com média anual de temperatura de 19,2 "C e precipitação média anual de $1207 \mathrm{~mm}$. As temperaturas médias mensais oscilam entre $14^{\circ} \mathrm{C}$ (junho) e $23^{\circ} \mathrm{C}$ (fevereiro). As precipitações médias mensais vão de $230 \mathrm{~mm}$ (janeiro) a $40 \mathrm{~mm}$ (agosi.), quando ocorre déficit hídrico no solo (GorresioRoizman 1993).

Grande parte da área da Reserva é coberta por mata sccunclária (Cersósimo 1993), considerada por Rossi (1994) como um mosaico de áreas em diversos estádios de degradação e regeneração, que representa um dos poucos remanescentes da cobcrtura florestal na cidade de São Paulo. O trabalho de Rossi (1994) foi o primeiro no sentido de se conhecer profundamente a flora da área. A autora estudou apenas plantas arbóreas c arbustivas, identificando 119 espécies nativas e mais 30 exóticas. A florística de outras formas de vida não é conhecida em profundidade. Esta floresta, situada no domínio das florestas ombrófilas densas, apresenta relações florísticas com a floresta ombrófila densa atlântica e a floresta estacional semidecidual (sensu Veloso et al. 1991) do Estado de São Paulo.

O local, cercado e fechado por tela de arame em agosto de 1979 (Rossi 1994), foi e continua sendo objeto de estudos de pesquisadores e alunos do Instituto de Biociências (Joly 1950, Varanda 1977, Meguro et al. 1979ab, 1980, Brandão 1980, Cersósimo 1993, Gorresio-Roizman 1993, Fonsêca 1994, Hasui 1994, Rossi 1994, Dislich 1996, (rrandisoli 1997).

Coleta - As epífitas, via de regra, não podem ser coletadas com tesoura de poda alta, pois normalmente são ervas para cuja identificação é muitas vezes necessária a coleta da planta inteira. Fez-se necessário, assim, o acesso direto ao alto das árvores. Para isso foram utilizadas técnicas de corda simples ("single-rope techniques"). Este método foi desenvolvido por Perry (1978) e utilizado por ele em conjunto com a rede de cordas (Perry \& Williams 1981) para estudar a floresta tropical na Costa Rica (Perry 1984, 1991). O método, também utilizado durante este trabalho para a subida nas árvores da Reserva, foi descrito por Nadkarni (1988). Outras contribuições foram feitas por Whitacre (1981), Dial e Tobin (1994) e Laman (1995). Outra técnica utilizada durante este trabalho para a escalada de árvores foi o "método das peconhas", apresentado por Oliveira c Zaú (1995). Uma variação é apresentada por Donahue e Wood (1995). Ele é indicado para subida em árvores de tronco longo, sem muitas ramificações. Com o uso destes dois métodos ficou viável o acesso direto às epífitas.

A mata foi visitada durante três anos (de 1993 a 1995), em intervalos irregulares. Procurou-se percorrer toda a extensão da Reserva, não seguindo trilhas determinadas, observando-se as cpífitas a partir do chão. Em algumas ocasiões também foi feita a escalada de árvores grandes, à procura de exemplares que não pudessem ser avistados de baixo.

Foram coletadas as plantas encontradas em estado fértil e aquelas que, mesmo não apresentando flor ou fruto, eram reconhecidas como sendo diferentes das já coletadas. No caso das Orchidaceae, plantas raras na Reserva, uma parte da planta era coletada, tomando-se o cuidado de deixar uma porção que assegurasse a sua sobrevivência no local. A parte coletada cra mantida 
em cultivo, ao ar livre e sobre xaxim, à espera da floração, para posterior identificação.

Também foram feitas observações do lado de fora da Reserva, principalmente de árvores nas suas imediações c daquelas que compõem a arborização urbana de São Paulo, em busca das espécies de epífitas observadas dentro da Reserva.

Identificação - Uma vez coletado, o material vegetal foi prensado e seco em estufa no Departamento de Ecologia Geral do Instituto de Biociências da Universidade de São Paulo. Depois de identificadas, as plantas foram incluídas na coleção do herbário do Departamento de Botânica do Instituto de Biociências (SPF).

A identificação das epífitas foi feita através do auxílio de especialistas e/ou de consulta à bibliografia, as-

Tabela 1. Famílias e espécies de epífitas vasculares na Reserva da (.UASO, São Paulo, SP. O asterisco indica as espécies exóticas.

\begin{tabular}{|c|c|}
\hline Familia & Espécic \\
\hline Araceac Juss. & $\begin{array}{l}\text { Philodendron bipinnatifidum Schott ex Endl. } \\
\text { Philodendron erubescensK. Koch \& Augustin*" } \\
\text { Pluilodendion imbe Schott } \\
\text { Philodendion propinquum Schot.t }\end{array}$ \\
\hline Araliaceac Juss. & Schefflera actinophylla (Endl.) Harms"* \\
\hline $\begin{array}{l}\text { Blechnaceac (C. } \\
\text { Presl.) Copel. }\end{array}$ & $\begin{array}{l}\text { Blechnum binervatum (Poir:) C.V.Morton \& } \\
\text { Lellinger }\end{array}$ \\
\hline Bromcliaceac Juss. & $\begin{array}{l}\text { Aechmea bromeliifolia (Rudge) Baker } \\
\text { Aechmea distichantha Lem. } \\
\text { Aechmea nudicaulis(L.) Griseb. } \\
\text { Billbcrgia zchrina(Herb.) Lindl. } \\
\text { Tillandsia gcminiflora Brongn. } \\
\text { Tillandsia recurvata (L.) L. } \\
\text { Tillandsia stricta Sol. } \\
\text { Vriesea gigantea Gaudich. }\end{array}$ \\
\hline Cartaceac Juss. & $\begin{array}{l}\text { Rhipsalis grandiflora Haw. } \\
\text { Rhipsalis teres (Vell.) Steudel } \\
\text { Rhipsalis trigona Pfeiff. }\end{array}$ \\
\hline Moraccate Link. & $\begin{array}{l}\text { Ficus luschnatiana (Miq.) Miq. } \\
\text { Ficus insipicla Willd. } \\
\text { Ficus microcarpa L.f." } \\
\text { Ficus hirsuta Schott }\end{array}$ \\
\hline Orchidaceac Juss. & $\begin{array}{l}\text { Campylocentrum linearifolium Schltr. ex } \\
\text { Mansf. } \\
\text { Epidcndrum sp. } \\
\text { Eunystyles cotyledon Wawna } \\
\text { Notylia longispicata Hochne \& Schltr. } \\
\text { Oncidium pumilum Lindl. } \\
\text { Polystachya estrellensis Reichb.f. }\end{array}$ \\
\hline Piperaceac C.Agardh & Peperomia urocarpa Fisch. \& C.A.Mey. \\
\hline $\begin{array}{l}\text { Polyporliaceae Bercht. } \\
\text { \& J.Presl }\end{array}$ & 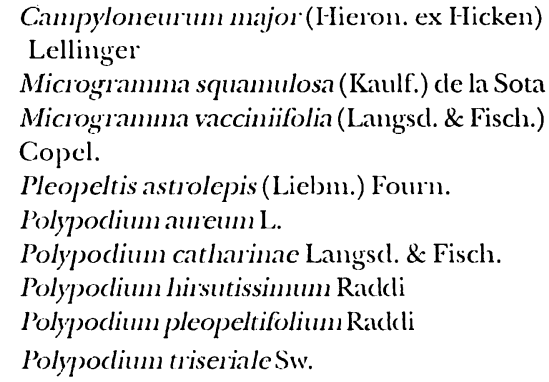 \\
\hline
\end{tabular}

sim como através de comparação com material do herbário do Instituto de Botânica (SP) e do Departamento de Botânica do Instituto de Biociências (SPF). Procurou-se identificar as plantas no nível de espécie, o que não foi possível apenas no caso de uma Orchidaceae da qual não se conseguiu material fértil.

As descrições de famílias e gêneros foram baseadas na bibliografia citada após cada descrição de família. As descrições de espécies foram feitas com base no material examinado. O exame de material de herbário limitouse a excmplares coletados nas proximidades da Reserva, incluindo os bairros de Butantã, Pirajussara, Cidade Jardim e Pinheiros. Os termos morfológicos nas descrições são usados de acordo com Ferri et al. (1981) e Radford et al. (1974). As abreviações dos nomes de autores foram feitas segundo Brummitt e Powell (1992). Os sistemas de classificação adotados foram os de Cronquist (1981) para as Magnoliophyta e Tryon e Tryon (1982) para as Pteridophyta. Foram elaboradas chaves de identificação nos níveis de família, gênero e espécie. Para permitir a identificação das espécies epifíticas em campo, em qualquer período do ano, foi efetuada uma chave baseada exclusivamente em características vegetativas.

\section{Resultados}

Durante este trabalho foram encontradas no interior da Reserva 37 espécies de epífitas vasculares, pertencentes a 20 gêneros de 9 famílias. Deste total, três são exóticas (Tabela 1). A seguir são apresentadas chaves de identificação e descrições para as famílias, gêneros e espécies presentes, assim como uma chave de identificação das espécies baseada em características vegetativas.

\section{Pteridophyta}

Chave para as famílias de Pteridophyta

1. Venação paralela .................................... Blechnaceae 1'. Venação reticulada ou inconspícua .. Polypodiaceae

\section{BLECHNACEAE (C.Presl.) Copel.}

Rizoma ereto, decumbente, reptante ou escandente, com escamas. Folhas monomórficas a dimórficas; pecíolo sem estípulas, não articulado ao rizoma; lâmina inteira a usualmente pinatissecta ou 1-2-pinada; nervuras totalmente livres ou em parte anastomosadas. Soros alongados, em um arco exterior de uma aréola ou em uma comissura vascular contínua ou parcialmente acrosticóides; cobertos por um indúsio ou exindusiados; esporangios com um pedúnculo 2-3-seriado e um anel vertical ou aproximadamente vertical, usualmente interrompido pelo pedúnculo. 
Bibliografia: Sehnem (1968), Tryon e Tryon (1982), Tryon c Stolze (1993).

\section{Blechnum L.}

Blechnum binervatum (Poir.) C.V.Morton \& Lellinger, Amer. Fern J. 57: 67. 1967.

Blechnum meridense (Klotzsch) Mett., Fil. hort. lips. 61. 185 ().

Rizoma densamente coberto por escamas. Folhas dimórlicas; pecíolo 10-20 cm compr:; lâmina estéril 35-80 cin compr., glabra, oblongo-lanceolada, atenuada para o ápice e para a base, acuminada, pinatissecta, ápice pinatíliclo; segmentos lineares, ereto-patentes, acuminados, $8-15 \mathrm{~cm}$ compr., os inferiores reduzidos a algumas aurículas largas e muito curtas; nervuras simples ou furcadas, paralelas; lâmina fértil mais curta, segmentos afastados. Soros com indúsio castanho, inteiro.

Matcrial examinado: Reserva da CUASO, 24.VIII.1994, R. Dislich 103.

Distribuição geográfica: sul do México e América Central; Venezuela e Colômbia, estendendo-se ao sul até a Bolívia; sudeste do Brasil (Tryon \& Stolze 1993), BA, M( , RJ, SP, PR, SC e RS (Sehnem 1968).

Representada por Blechnum binervatum ssp. acutum (Desv.) Tryon \& Stolze, é encontrada às margens do riacho, normalmente sobre Cyathea delgadii Sternb. (samambaiaçu), em alturas entre 1 e $3 \mathrm{~m}$. Não foram observadas plantas jovens no solo, mas os restos de rizoma ao longo do tronco do suporte indicam que há possibilidade de se tratar de hemiepífita secundária, germinando no solo, posteriormente subindo pelo suportc c mais tarde perdendo a conexão com o solo (cli. as espécies de Araceae). Foram encontradas também plantas jovens que germinaram diretamente sobre o suporte.

\section{POLYPODIACEAE Bercht. \& J.Presl}

Rizoma ereto a reptante ou pendente, portando escamas. Folhas monomórficas a dimórficas; pecíolo scm estípulas, freqüentemente articulado ao rizoma; lâmina inteira, pinatífida, variadamente ramificada ou pinarla; nervuras livres a anastomosadas. Soros redonclos a alongados, originando-se em uma nervura, na ponta de uma nervura ou na.junção de nervuras, ou então esporângios originados em uma comissura vascular ou em uma série especial de nervuras férteis; exinclusiados; esporângios com um pedúnculo basal 1- ou 2-seriado, o anel vertical interrompido pelo pedúnculo.
Bibliografia: Sota (1960), Sehnem (1970), Tryon e Tryon (1982), Lellinger (1988), Tryon e Stolze (1993).

Chave para os gêneros de Polypodiaceae 1. Lâmina pinatífida, pinatissecta ou pinada ... Polypodium

1'. Lâmina inteira

2. Venação inconspícua Pleopeltis 2'. Venação distinta

3. Mais de uma série de soros entre a nervura central e a margem; folhas monomórficas ...... Campyloneurum

3'. Apenas uma série de soros entre a nervura central e a margem; folhas dimórficas (as férteis mais estreitas e compridas que as estéreis) Microgramma

\section{Campyloneurum C.Presl}

Campyloneurum major (Hieron. ex Hicken) Lellinger, Amer. Fern J. 78. 1988.

Rizoma reptante, tortuoso, no ápice coberto por escamas castanho-pardas, arredondadas. Folhas monomórficas; pecíolos curtos, angulosos, glabros; lâminas eretas, simples, inteiras, oblongo-lanceoladas, base e ápice atenuados, $20-100 \mathrm{~cm}$ compr.; nervuras primárias em ângulo de $60^{\circ}$ com a costa, emersas, paralelas, distantes entre si $0,4-0,8 \mathrm{~cm}$; secundárias formando 4-8 arcos entre as primárias. Soros redondos, em mais de uma série entre a nervura central e a margem.

Material examinado: Reserva da CUASO, 13.V.1993, $R$. Dislich 3; 17.V.1994, R. Dislich 94; 22.VIII.1994, R. Dislich 97.

Distribuição geográfica: AM, BA, MG, RJ, SP, PR, SC e RS. Flórida até sul do Brasil e Argentina (Sehnem 1970).

Ocorre como epífita a até três metros de altura, à margem do riacho, e também como terrestre, condição em que foi encontrada apenas uma vez.

\section{Microgramma C.Presl}

Plantas epífitas ou rupícolas. Rizoma longo, reptante ou pendente. Folhas monomórficas a dimórficas, 1$35 \mathrm{~cm}$ compr.; lâmina inteira, levemente pubescente, levemente a moderadamente escamosa, ou glabra; nervuras livres a anastomosadas, usualmente com vênulas livres incluídas. Soros redondos a alongados, sobre uma nervura, na ponta dela ou na junção de nervuras, parafisados ou não, exindusiados. 
Chave para as espécies de Microgramma

1. Folhas estéreis pecioladas, com base atenuada

M. squamulosa

l'. Folhas estéreis sésseis, com basc cuncada a truncada M. vacciniifolia

Microgramma squamulosa (Kaulf.) de la Sota, Opera Lilloama 5: 59. 1960 .

Polypodium squamulosum Kaulf., Enum. 89. 1824.

Rizoma reptante-escandente, ramificado, densamente coberto por escamas. Folhas dimórficas; pecíolos 0,5-4 cm compr.; lâminas estércis elípticas a oblongas, base atenuada, ápice obtuso ou agudo, 15 $\mathrm{cm}$ compr.; lâminas férteis lineares, $3-10 \mathrm{~cm}$ compr.; nervuras anastomosadas, muito nítidas; costas com escamas brancas.

Material examinado: Butantã, 17.IV.1917, F. C. Hochnes. 1. (SP 48); 08.IV.1994, I.B. Suffredini s. n. (SPF 86153); Mata da Reserva da CUASO, 22.V.1976, R.C.Mcndonça, V.F.Silveira, F.P.Millan, L.P.Fujiara, E.Kubo s. n. (SPF 93185); 13.V.1993, R. Dislich 4; 21.V.1993, R. Dislich 8; 03.V.1994, R. Dislich 83, R. Dislich 84.

Distribuição geográfica: MG, RJ, SP, PR, SC e RS, México, Peru, Argentina, Uruguai (Schnem 1970); também Bolívia e Paraguai (Tryon \& Stolze 1993).

Uma das epífitas mais abundantes na Reserva e arredores, cobre grandes porções das árvores, desde os troncos atć ramos de $1 \mathrm{~cm}$ de diâmetro. Também ocorre como rupícola. É muito freqüentemente encontrada sobre as árvores mais antigas que compõem a arborização urbana de São Paulo.

Microgramma vacciniifolia (Langsd. \& Fisch.) Copel., Gen. Fil. 185. 1947.

I'olypodium vaccinifolium Langsd. \& Fisch., Ic. Fil. 8, t. 7. 1810.

Rizoma reptante ou pendendo em fios, ramificado, densamente coberto por escamas. Folhas dimórficas; lâminas estéreis sésseis, clípticas ou ovais a quasc oblongals, base obtusa ou truncada, ápice obtuso, $1,5-3 \mathrm{~cm}$ compr; lâminas Férteis sésseis ou com pecíolo curto, lincares, 3-7 cm compr.; nervuras anastomosadas, nítidas; costas sem escamas.

Matcrial examinado: Butantan, 1920, F. C. Hoehnes. n. (SP 5779); Cidade Jardim, V.1941, W. Hoehne 656 (SPF 1)724); Reserva da CUASO, 21.V.1993, R. Dislich 9.

Distribuição geográfica: Jamaica, Granada, Trinidad e Tobago, Venezuela e Colômbia se estendendo ao sul até Paraguai e Argentina (Tryon \& Stolze 1993). BA, RJ, SP, SC e RS (Sehnem 1970).

Normalmente encontrada pendendo dos galhos das árvores, sob forma de longos fios (até $3 \mathrm{~m}$ de comprimento).

\section{Pleopeltis Humb. \& Bonpl. ex Willd.}

Pleopeltis astrolepis (Liebm.) Fourn., Mexic. pl. 1: 87. 1872.

Polypodium astrolepis Liebm., Kongel. Danske Vidensk. Selsk, Skr., Naturvidensk. Afd., ser. 5, 1: 185. 1849.

Pleopeltis revoluta (Willd.) A.R.Sm., Proc. Calif. Acad. Sci. 40: 230. 1975

Rizoma longo, reptante, coberto por escamas arredondadas. Folhas monomórficas; pecíolos negros como a nervura central, $1-2 \mathrm{~cm}$ compr., estreitamente alados, providos de minúsculas escamas estelares, como toda a planta; lâmina simples, inteira, linear ou alongado-lanceolada, 3-12 cm compr., 0,5-0,8 cm larg., base atenuada, ápice agudo; nervuras completamente imersas, inconspícuas. Soros levemente alongados, parafisados, exindusiados.

Material examinado: Reserva da CUASO, 07.III.1994, $R$. Dislich 60; 29.IV.1994, R. Dislich 76.

Distribuição geográfica: México a Panamá; Índias Ocidentais; Colômbia a Guianas, estendendo-se ao sul até Bolívia e Brasil (Tryon \& Stolze 1993); PI, MG, RJ, PR e SC (Sehnem 1970).

É epífita comumente encontrada. Ocorre também como rupícola e epífita nos arredores da Reserva.

\section{Polypodium L.}

Plantas terrestres, rupícolas ou epífitas. Rizoma curto a longo, reptante. Folhas monomórficas a dimórficas, $4-200 \mathrm{~cm}$ compr.; Lâmina inteira, pinatifida, pinatissecta ou 1-pinada ou raramente 2-pinada-pinatifida ou 3-pinada, glabra, pubescente ou esparsa a densamente escamosa; nervuras livres ou anastomosadas, com ou sem vênulas incluídas. Soros redondos a alongados, na ponta de uma nervura ou na junção de nervuras, parafisados ou não, exindusiados.

Chave para as espécies de Polypodium

1. Mctade basal da lâmina pinatissecta ou pinatífida. 2. Segmentos da lâmina eretos ....... P. pleopeltifolium 2'. Segmentos da lâmina patentes.

3. Segmento apical maior que os laterais

P. aureum 
3'. Segmento apical menor que os laterais P. catharinae

l'. Metade basal da lâmina pinada.

4. Lâmina densamente recoberta por pêlos; pinas alé $3 \mathrm{~cm}$ de comprimento .......... P. hirsutissimum

4'. Lâmina glabra ou muito pouco pubescente; pinas com mais de $7 \mathrm{~cm}$ de comprimento P. triseriale

Polypodium aureum L., Sp. pl. 1087. 1753.

Phlebodium aureum (L.) John Sm., J. Bot. (Hooker) 4: 5). 1841.

Rizoma reptante, geralmente curto, densamente recoberto por escamas. Folhas monomórficas; lâmina profundamente pinatifida, base não atenuada, $40 \mathrm{~cm}$ compr. ou mais; segmentos patentes, abaxialmente muito pouco escamosos ou glabros, o apical mais longo que os laterais; nervuras conspícuas, anastomosadas. Soros em 1 ou 2 séries entre costa e margem.

Material examinado: Reserva da CUASO, 24.II.1995, $R$. Dislich 166 .

Distribuição geográfica: América tropical (Tryon \& Stolze 1993).

Epífita rara na Reserva, foi encontrado apenas um indivíduo sobre Machaerium nictitans(Vell.) Benth., na mesma região da mata em que ocorre Vriesea gigantea (Bromeliaceae). A espécie é ornamental e amplamente cultivada.

Polypodium catharinae Langsd. \& Fisch., Ic. Fil. 10, t. 10. 1810 .

Rizoma reptante, até $40 \mathrm{~cm}$ compr., revestido de escamas principalmente nas pontas das gemas. Folhas monomórficas; lâmina pinatissecta, de base não atenuada, atenuada no ápice, até $35 \mathrm{~cm}$ compr.; segmentos patentes, glabros, $1,5-6 \mathrm{~cm}$ compr., os maiores na base; nervuras conspícuas, formando duas séries de malhas, incluindo uma livre. Soros em uma série de cada lado da costa.

Material examinado: Reserva da CUASO, 13.V.1993, $R$. Dislich 2; 14.III.1994, R. Dislich 66; ()3.V.1994, R. Dislich S2; ()2.IX.1994, R. Dislich 111; ()5.X.1994, R. Dislich 1.30; 30.1.1995, R. Dislich 161.

Distribuição geográfica: MG, SP, PR, SC, RS, Costa Rica, México (Sehnem 1970).

Epífita relativamente freqüente. Apresenta tendência à queda de folhas na época mais seca do ano, provavelmente como mecanismo de retenção de água. Também ocorre em árvores isoladas fora da Reserva.
Polypodium hirsutissimum Raddi, Op. Sci. Bol. 3: 286. 1819.

Rizoma reptante, moderadamente longo, densamente coberto por escamas. Folhas monomórficas; lâmina pinada, atenuada para os dois extremos, até $40 \mathrm{~cm}$ compr.; pinas sésseis, patentes, densamente pilosas, 0,3-3 cm compr.; nervuras inconspícuas. Soros em uma série entre costa e margem.

Material examinado: Reserva da CUASO, 13.V.1993, $R$. Dislich 5, R. Dislich 6; 21.V.1993, R. Dislich 7; 03.V.1994, R. Dislich 88 .

Distribuição geográfica: RJ, PR, SC e RS, Uruguai, Argentina, Paraguai (Sehnem 1970).

Relativamente comum, apresenta comportamento poiquiloídrico, tendo aspecto bem diferente dependendo do grau de hidratação. Ocorre também como rupícola. Comumente encontrado sobre árvores nas ruas da cidade de São Paulo.

Polypodium pleopeltifolium Raddi, Opusc. Sci. Bol. 3: 1819.

Pleopeltis pleopeltifolia (Raddi) Alston, Bol. Soc. Broteriana 30(2): 21.1956.

Rizoma reptante, curto, no ápice recoberto por escamas. Folhas monomórficas; lâmina pinatissecta, base atenuada, até $15 \mathrm{~cm}$ compr.; segmentos eretos, pontilhados de escamas, $4-8 \mathrm{~cm}$ compr., os mais compridos na base; nervuras completamente imersas, inconspícuas. Soros em uma série entre costa e margem.

Material examinado: Reserva da CUASO, 23.VI.1993, $R$. Dislich 13.

Distribuição geográfica: CE, BA, GO, MT, MG, ES, RJ, SP, PR, SC, RS, Paraguai, N do Uruguai, NE da Argentina (Sota 1960, Sehnem 1970).

Ocorre como epífita verdadeira. Apresenta comportamento poiquiloídrico, ficando totalmente ressecada e enrugada quando não chove, porém sem morrer.

Polypodium triseriale Sw., J. Bot. (Schrader) 1800(2): 126. 1801.

Rizoma de curto a longo, com escamas no ápice. Folhas monomórficas; lâmina pinada, até $90 \mathrm{~cm}$ compr., não ou muito pouco reduzida na base; pinas sésseis, patentes, muito pouco pubescentes ou escamosas abaxialmente, $7-10 \mathrm{~cm}$ compr.; nervuras conspícuas, anastomosadas. Soros em (1-)2-3(4) séries entre costa e margem.

Material examinado: Reserva da CUASO, 24.II.1995, $R$. Dislich 167. 
Distribuição geográfica: América tropical (Tryon \& Stolze $1993)$.

Epífita rara na Rescrva, tendo sido encontrado apenas um indivíduo, sobre a mesma árvore que Polypodium aureum.

\section{Magnoliophyta}

Chave para as famílias de Magnoliophyta

1. Plantas áfilas ...................................... Cactaceae

1'. Plantas com folhas.

2. Folhas pecioladas.

3. Plantas com látex

Moraceae

3'. Plantas sem látex.

4. Folhas digitadas, estípula axilar ... Araliaceae

4'. Folhas inteiras, pinatífidas ou sagitadas, sem estípula axilar.

5. Limbo de folha adulta com até $4,5 \mathrm{~cm}$ de compr.

Piperaceac

5'. Limbo de folha adulta com mais de 10

cm de compr.

Araceae

2'. Folhas sem pecíolo.

7. Folhas congestas, formando roseta.

8. Folhas oboval-oblongas .......... Orchiclaceae

8 '. Folhas lineares, liguladas ou estreitamente triangulares Bromcliaceac

7'. Folhas distantes entre si.

9. Folhas densamente recobertas por escamas Bromeliaceac

9'. Folhas glabras Orchiclaceae

\section{ARACEAE Juss.}

Ervas cretas, reptantes ou escandentes, raramente flutuantes. Folhas alternas ou rosuladas, simples a compostas, às vezes fenestradas; estípulas ausentes. Inflorescência simples, tipo espádice, envolta por uma espata. Flores monóclinas ou díclinas, sem perianto ou com, neste caso com 4 ou 6(8) tépalas em duas séries; estames (1-)4 ou 6(8); ovário súpero, uni ou plurilocular, 1 vários óvulos por lóculo. Frutos bagas, às vezes concrescidas.

Bibliografia: Engler e Krause (1913), Reitz (1957), Barroso (1962), Mayo (1991).

Foram encontrados 4 representantes desta família, todos hemiepífitas do gênero Philodendron. Varanda (1977) citou a presença de Philodendron acutatum Schott, nào encontrado durante este trabalho. Trata-se provavelmente de uma identificação equivocada; scgundo descrição em Engler e Krause (1913) o formato das folhas desta espécic é similar ao da espécie de Araceae mais comum na Reserva $(P$. imbe), mas $P$ acutatum é nativa da Venezuela e das Guianas.

\section{Philodendron Schott}

Plantas na maioria escandentes, epífitas, algumas vezes terrícolas ou rupícolas, raramente arborescentes. Folhas com lâmina foliar elíptica a lanceolada, oblanceolada, ovada ou cordada, inteira ou pinatifida, em geral coriácea. Eapata persistente na frutificação, com tubo basal e lâmina apical. Espádice séssil ou curtamente estipitada, parte apical estaminada, parte basal pistilada. Flores unissexuais, aclamídeas; estames 2-6; ovário 2-multilocular; óvulos geralmente em 2 fileiras em cada lóculo; estilete tão largo quanto o ovário, pouco conspícuo ou ausente. Sementes 1 a muitas em cada fruto.

Chave para as espécies de Philodendron

1. Lâmina foliar com margem pinatífida P. bipinnatifidum

1'. Lâmina foliar com margem inteira.

2. Base da lâmina foliar aguda ou obtusa P. propinquum

2'. Base da lâmina foliar cordado-sagitada.

3. Catáfilos apicais e face abaxial das folhas rósco-avermelhados. P. erubescens

3'. Catáfilos apicais e face abaxial das folhas verde-claros P. imbe

Philodendron bipinnatifidum Schott ex Endl., Gen. Pl. 1(3): 237.1837.

Philodendron selloum K.Koch, Index sem. hort. reg. bot. berol., Appendix: 14. 1854.

Planta arborescente, terrícola ou epífita. Catafilos triangulares, até $40 \mathrm{~cm}$ compr., verdes-claros. Pecíolo 40-90 cm compr., sem alas; lâmina cordado-sagitada, pinatífida, $50-120 \mathrm{~cm}$ compr., face abaxial verde-clara. Espata internamente branca, com tubo externamente verde ou avermelhado, $3-6,5 \mathrm{~cm}$ compr., lâmina mais clara, 13-26 cm compr. Espádice 17-22 cm compr.

Material examinado: Mata do campus (USP), 1983, Hylio, Alexandre, Ricardo, Jean s. 11. (SPF 33339); Reserva da CUASO, 29.IV.1994, R. Dislich 75.

Fenologia: não encontrada em estado fértil dentro da Reserva.

Distribuição geográfica: desde RJ, MG e MT até RS (Reitz 1957).

Rara dentro da Reserva, tendo sido observados apenas dois indivíduos sobre uma mesma árvore e mais um na parte alta da Reserva, próximo à borda. Apresenta-se como hemiepífita primária não estrangulante, 
germinando sobre o forófito (galhos grossos, com pequena inclinação, ou em forquilhas). Lança raízes aéreas ou que acompanham o tronco do forófito, alongando-se até estabelecerem contato com o solo. Ocorre também nos arredores da Reserva, principalmente nos jardins do Instituto de Biociências, como hemicpífita primária, espontaneamente, sempre muito jovem; como planta terrestre, cultivada; ou como hemiepífita secundária, quando uma planta terrestre encontra uma árvore que lhe serve como suporte. Muito apreciadla como ornamental.

Philodendron erubescens K.Koch \& Augustin, Ind. sem. hort. Berol. App. 6. 1854.

Planta escandente ou epífita. Catafilos linear-lanceolarlos, $7-10 \mathrm{~cm}$ compr., róseo-avermelhados. Pecíolo $15-25 \mathrm{~cm}$ compr., sem alas; lâmina cordado-sagitada, até 3() $\mathrm{cm}$ compr., face abaxial róseo-avermelhada. Espala internamente carmim, externamente atropurpúrea, com tubo $7-8 \mathrm{~cm}$ compr., lâmina $7 \mathrm{~cm}$ compr. Espádice $15 \mathrm{~cm}$ compr.

Matcrial examinado: Reserva da CUASO, 08.VI.1995, $R$. Dislich 173.

Fenologia: não encontrada em estado fértil durante este l.raballho.

Distribuição geográfica: Colômbia (Engler \& Krause $1913)$.

Ocorre na parte alta da Reserva, próxima ao riacho. Trata-se de hemiepífita secundária, germinando no solo e crescenclo de forma reptante até encontrar o tronco de alguma árvore, por onde vai, então, subindo. O caule posterior vai se decompondo, e a planta acaba perdendo contato com o solo. Pode ser considerada planta invasora na Reserva, uma vez que a espécie não é nativa clo Brasil. É, porém, utilizada como ornamental, e pode ter sido levada para dentro da mata através de scmentes trazidas por pássaros, ou então diretamente introduzida pelo homem. Rossi (1994) citou esta espécie como o Philodendron mais comum na Reserva, o que provivelmente se deve a uma confusão com $P$. imbe, muito abundante no local.

Philodendron imbe Schott, Wien. Zeitschr. 3: 780. 1829.

l'lanta escandente ou epífita. Catafilos linear-lanceolarlos, 7-15 cm compr., verdes-claros. Pecíolo 25-35 cm compr., sem alas; lâmina cordado-sagitada, 20-40 cm compr., face abaxial verde-clara. Espata com tubo $3,5-5 \mathrm{~cm}$ compr., exteriormente verde, internamente vermelho, lâmina $6-10 \mathrm{~cm}$ compr., em ambas as faces pálido-amarelada. Espádice $8-15 \mathrm{~cm}$ compr.
Material examinado: Reserva da CUASO, 16.III.1994, $R$. Dislich 72; 03.V.1994, R. Dislich 86; 24.VIII.1994, $R$. Dislich 99; 08.VI.1995, R. Dislich 171, 172.

Fenologia: Coletado com infrutescência em agosto.

Distribuição geográfica: PE a RS (Reitz 1957).

Bastante comum dentro da Reserva, principalmente próxima às margens do riacho. Comporta-se como hemiepífita secundária. Às vezes, já em condição epifítica, a planta lança raízes aéreas que acabam chegando até o solo, refazendo a conexão.

Philodendron propinquum Schott, Syn. Aroid. 78. 1856.

Planta escandente ou epífita. Catafilos ausentes. Pecíolo até $18 \mathrm{~cm}$ compr., alado; lâmina inteira, oblonga, $12-25 \mathrm{~cm}$ compr., verde, base aguda ou obtusa. Espata ca. $7,5 \mathrm{~cm}$ compr., branca, tubo quase do mesmo tamanho da lâmina. Espadice $6,5 \mathrm{~cm}$ compr.

Material examinado: Reserva da CUASO, 10.IV.1990, P.T. Sano \& R. Dislich 21;16.III.1994, R. Dislich 73.

Fenologia: Não observada em estado fértil dentro da Reserva.

Distribuição geográfica: MG, RJ (Barroso 1962), SP.

Apresenta a mesma forma de crescimento que Philodendron imbe, mas usualmente não lança raízes aéreas. Parece, também, haver uma maior tendência a manter a conexão com o solo, através do caule antigo. Comum próximo às margens do riacho.

\section{ARALIACEAE Juss.}

Árvore, arbustos ou plantas escandentes, terrestres ou epífitas. Folhas alternas, simples ou pinadas ou digitadas. Estípulas presentes ou ausentes. Inflorescência em panícula, racemo ou capítulo. Flores monóclinas ou às vezes díclinas, cálice com pequenos dentes, pétalas (3-) 5 (12); Estames em número igual ao de pétalas; ovário ínfero, raramente semi-ínfero ou súpero, 2-12locular; um óvulo por lóculo. FRUTO drupa ou baga.

Bibliografia: Harms (1898), Graf (1992).

\section{Schefflera J.R.Forst. \& G.Forst.}

Schefflera actinophylla (Endl.) Harms, Natürl. Pflanzenfam. 3(8): 36. 1894.

Brassaia actinophylla F.Muell., Fragm. 4: 121.

Planta ereta, lenhosa. Estípulas axilares nítidas, agudas. Folhas alternas, pecioladas, digitadas, folíolos peciolulados, ovais, de base arredondada e ápice 
acuminado. Flores sésseis, em capítulos densos, pedicelados c reunidos em cachos; pétalas 10-12; estames cm número igual ao de pétalas; ovário ínfero, 10-12locular.

Material examinado: Cidade Universitária, 15.II.1995, $R$. Dislich 165; Reserva da CUASO, 02.IX.1994, R. Dislich 112, 3().I.1995, R. Dislich 162.

Fenologia: na Cidade Universitária, plantas adultas florindo $\mathrm{em}$ janeiro.

Distribuição geográfica: Austrália, Papua, Nova Guiné, Java e Polinésia (Harms 1898, Graf 1992).

Na Reserva foram encontrados dois indivíduos jovens, não férteis, com cerca de $50 \mathrm{~cm}$ de altura. Os indivícluos estavam na condição epifítica, em grandes bifurcações de árvores, a mais de 4 metros de altura. Como não foi observado nenhum exemplar adulto dentro da Reserva, é possível que se trate de epífita efêmera, não chegando à fase adulta. A espécie, cxótica, é utilizada como ornamental de interiores e também na arborização de ruas, pois alcança porte de árvore. É cultivada também na Cidade Universitária, próximo às margens da Reserva, onde sementes germinam sobre a própria árvore que lhes deu origem. É possível que sementes tenham sido levadas para dentro da mata por pássaros. Graf (1992) encontrou esta espécic como epífita, a $30 \mathrm{~m}$ de altura, em Sogeri, Papua. Exemplares jovens também são encontrados na condição epifítica sobre árvores nas ruas da cidade de São Paulo.

\section{BROMELIACEAE Juss.}

Ervas terrestres, rupícolas ou epífitas. Estípulas auscntes. Folhas em roseta ou alternas, simples. Inflorescência simples ou composta. Flores monóclinas ou ratamente díclinas, 3 sépalas, 3 pétalas; estames 6; ovário súpero a ínfero, 3-locular, poucos a muitos óvulos por lóculo. Fruto cápsula ou baga.

Bibliografia: Smith e Downs (1977, 1979), Reitz (1983), Wanderlcy e Mollo (1992).

Joly (1950) citou várias bromélias epífitas para a "mata do Butantã", com trecho que é a Reserva hoje: Acchmea distichantha Lem. e Aechmea bromeliifolia (Rudgc) Baker, Tillandsia pulchella Hook. (atualmente consiclerada na sinonímia de Tillandsia tenuifolia L.), Tillandsia usneoides L. e Tillandsia stricta Sol. As duas primeiras também foram citadas por Rossi (1994). T. pulchclla não foi encontrada neste trabalho. $T$. usneoides ocorre nos jaudins do Instituto de Biociências, mas não foi encontrada dentro da Reserva. Rossi (1994) citou Aechmea lin- gulata Baker como presente na Reserva, mas esta planta não foi encontrada durante este trabalho. Varanda (1977) citou Vriesea sp., tendo-se encontrado uma espécie deste gênero, $V$. gigantea Gaudich.

Chave para os gêneros de Bromeliaceae

1. Folhas de margens espinoso-serradas.

2. Bainha mais larga que a lâmina foliar ...... Aechmea

2'. Bainha mais estreita que a base da lâmina foliar Billbergia

1'. Folhas de margens lisas.

3. Folhas com até $1 \mathrm{~cm}$ de largura ........... Tillandsia

3'. Folhas com mais de $4 \mathrm{~cm}$ de largura ........ Vriesea

\section{Aechmea Ruiz \& Pav.}

Eevas terrestres, rupícolas ou epífitas. Folhas em roseta densa ou fasciculadas, geralmente de margens espinoso-serrados. Inflorescência composta ou simples. Flores monoclinas, sésseis ou pediceladas; sépalas livres ou conatas, em geral fortemente assimétricas; pétalas livres, portando 2 lígulas basais mais ou menos adnatas; ovário ínfero, geralmente com indumento; óvulos na maior parte caudados. Fruto baga; sementes não apendiculadas.

Chave para as espécies de Aechmea

1. Inflorescência composta; flores dísticas

A. distichantha

1 '. Inflorescência simples; flores polísticas.

2. Inflorescência densa ..................... A. bromeliifolia 2'.Inflorescência laxa a sublaxa ........... A. nudicaulis

Aechmea bromeliifolia (Rudge) Baker in Bentham \& Hooker filius, Gen. Pl. 3: 664.1883.

Folhas 12-20, em roseta; bainha mais larga que a lâmina; lâmina ligulada, compr. não mais de 20 vezes a larg., serrada com espinhos antrorsos até $1 \mathrm{~cm}$ compr. Inflorescência simples, espiciforme, densa, elipsóide ou cilíndrica. Sépalas curto-conatas; pétalas amarelo-esverdeadas, logo tornando-se negras. Ovário tomentoso.

Material examinado: Butantã, 30.VII.1946, A. B. Jolys. $n$. (SPF 16760); Cidade Universitária, Jardim do Departamento de Botânica do Instituto de Biociências da USP, 12.VII.1993, J. R. Pirani, L. Lohmann, S. C. Galassi, S. Marchini s. 11. (SPF 78037); Jardins do Butantã, Campus da USP, 1983, Hylio, Alexandre, Ricardo, Jean s. 11. (SPF 34337); Mata do Instituto de Biociências, 15.VII.1994, M. Batalla \& C. M. Mello 1 (SPF 89359); Pirajussara, 03.VIII.1930, A. Gehrt 42 (SPF 10284); Reserva da CUASO, 03.V.1994, R. Dislich 80, R. Dislich 81 . 
Fenologia: encontrada florindo de maio a agosto (algumas plantas chegando até outubro) e com frutios de agosto a outubro.

Distribuição geográfica: AM, RO, AP, PA, CE, PB, BA, MG, C,O, DF, MG, SP, PR, SC e RS. Desde a Guatemala, pela América Central, até a Argentina (Reitz 1983).

É clas epífitas mais conspícuas e importantes na Rescrva c a Bromeliaceae mais comum, ocorrendo em toda a sua árca. Dentro da mata ocorre exclusivamente como epíliıa verdadeira, germinando sobre a árvore e permancecndo ali, sem estabelecer contato com o solo. Eventualmente pode ser encontrada sobrevivendo e até florescendo no chão, após queda do galho cm que se encontrava, mas não consegue se estabelecer definitivamente nesta condição. É típica epífita de tanque. Forma grandes colônias, com folhas bem compridas, $\mathrm{cm}$ locais mais sombreados, principalmente bifurcações, ou então ocorre em lugares mais ensolarados, em colôniats menores ou isolada, com folhas mais curtas e tanque bem definido. Nos jardins do Instituto de Biociências é cultivada no chão, sobre areia, e também ocore espontaneamente como epífita. Aparece também espontaneamente como epífita nas árvores que ladciam a Rua do Matão, limite da Reserva a oeste. $\mathrm{O}$ excmplar coletado por Joly (SPF 12760) estava no campo, sobre rochas.

Acchmea distichantha Lem., Jard. Fleur. 3: t. 269.1853.

Folhas 15-25, em roseta; bainha mais larga que a lâmina; lâmina estreitamente triangular a ligulada., compr: mais de 40 vezes a larg., margens com acúleos castanhos, 2-3 $\mathrm{mm}$ compr., curvos para ópice. Inflorescência paniculada, subfusiforme; ramos polísticos, 2-7-[lorais, disticamente espiciformes. Sépalas vermethas, com indumento branco-farinoso, concrescidas na basc; Pétalas com a metade inferior branca, o resto violáceo. Ovário branco-farinoso.

Material examinado: Butantã, 30.VIII.1946, A. B. Jolys. n. (SPF 16761); Campus da USP, 1983, Hylio, A. Mello, R. Hanakawa, J. Buffet s. n. (SPF 34338); Cidade Jardim, 15.VIII.1934, W. Hoehne 323 (SPF 3026); Pirajussara, ()3.VIII.1930, A. Gehrt 43 (SPF 10285); Reserva da CUAS(), 27.X.1993, R. Dislich 16.

Icnologia: observada em flor de maio a agosto e em outubro.

Distribuição geográfica: MG, RJ, SP, PR, SC e RS, Uruguai, Argentina e Paraguai (Reitz 1983).

Pouco freqüente dentro da mata, sempre como epífilta verdadeira. Também ocorre espontaneamente nos jardins do Instituto de Biociências e nas árvores da Rua do Matão. É também uma forma de tanque, ainda que não acumule tanta água quanto Aechmea bromeliifolia e A. nudicaulis, já que suas folhas são mais estreitas.

Aechmea nudicaulis (L.) Griseb., Fl. Brit. W. Indies 593. 1864.

Folhas ca. 10, em roseta; bainha quase da mesma larg. que a lâmina; lâmina ligulada, compr. 5-10 vezes a larg., margens com espinhos de 2 mm compr., escuros, patentes ou um pouco virados para o ápice. Inflorescência simples, espiciforme, laxa a sublaxa, cilíndrica. Sépalas amarelas, livres; pétalas amarelo-esverdeadas. Ovário tomentoso.

Material examinado: Butantã, 06.XI.1917, F. C. Hoehnes. n. (SP 865); 20.II.1918, F. C. Hoehne s. n. (SP 3046); Campus da USP, 1983, Hylio, A. Mello, R. Harakawa,J. Buffet s. 11. (SPF 34340); Cidade Jardim, 02.XI.1932, $W$. Hoehne s. n. (SPF 16762); Reserva da CUASO, 26.X.1993, R. Dislich 15 .

Fenologia: observada em flor em outubro.

Distribuição geográfica: BA, ES, MG, RJ, SP, PR, SC, RS, Venezuela e Equador (Reitz 1983).

Pouco freqüente na Reserva, esta espécie, representada por Aechmea nudicaulis var. cuspidata Baker, é epífita de tanque e forma colônias. À distância, plantas não férteis desta espécie podem ser difíceis de distinguir de Aechmea bromeliifolia. Como esta última, também apresenta formas de sol e de sombra. Ocorre também nos jardins do Instituto de Biociências, ainda que muito mais raramente que Aechmea bromeliifolia.

\section{Billbergia Thunb.}

Além da espécie apresentada, foi coletada uma outra nos jardins do Instituto de Biociências: Billbergia distachia(Vell.) Mez (27.IX.1996, R. Dislich 183). Desta planta também existem coletas para a região (Butantã, 10.VIII.1917, F. C. Hoehne s. n. (SP 395); Cidade Jardim, 20.IX.1932, W. Hoehne 26 (SPF 10029)), mas não foi encontrada no interior da Reserva.

Billbergia zebrina (Herb.) Lindl., Bot. Reg. 13: t. 1068. 1827.

Erva epífita. Folhas 5-6, em roseta, formando tubo cilíndrico; bainha mais estreita que a lâmina; lâmina ligulada, margens com espinhos de até $3 \mathrm{~mm}$ compr., eretos ou encurvados para o ápice. Inflorescência simples, espiciforme, cilíndrica, laxa. Flores $65 \mathrm{~mm}$ compr., sésseis; sépalas branco-farinosas, livres, pouco assimétricas; pétalas verde-amareladas, $56 \mathrm{~mm}$ compr., livres, com 2 lígulas retangulares concrescidas basal- 
mente às pétalas; ovário ínfero, tomentoso; óvulos apendiculados no ápice. Fruto baga. Sementes não apendiculadas.

Matcrial examinado: Reserva da CUASO, 08.VI.1995, $R$. Dislich 170.

Fenologia: encontrada com fruto em junho.

Distribuição geográfica: MG, RJ, SP, PR, SC, RS, Paraguai, Argentina (Reitz 1983).

Planta rara na Reserva, tendo sido encontrado apenas um indivíduo, em frutificação, sobre uma bifurcaÇão a 3 metros de altura, em região à direita do riacho. Epílita verdadeira, forma tanque. Pode ser difícil fazersc a distinção, principalmente à distância, entre Billbergia \%chrina, Acchmea bromeliifolia e A. nudicaulis, quando não estão férteis.

\section{Tillandsia L.}

Ervas epífitas ou rupícolas. Folhas em roseta ou fasciculadas ou distribuídas ao longo do caule, polísticas ou dísticas, de margens lisas. Inflorescência de espiga dístico-floral a uma simples flor. Flores monóclinas, com geral curto-pediceladas; sépalas livres ou conatas, geralmente simétricas; pétalas livres, sem apêndices; Ovário súpero, glabro; óvulos caudados. Fruto cápsula septicida; Sementes com um penacho basal, reto e branco.

Chave para as espécies de Tillandsia

1. Folhas clísticas T. recurvata 1'. Folhas polísticas.

2. Inflorescência composta ................. T. geminiflora

2'. Inflorescência simples ................................. T. stricta

Tillandsia geminiflora Brongn. in Duperrey, Voy. CoquiIle $18(j .1813$.

Folhas em grande número, em densa roseta; lâmina estreitamente triangular, $10-17 \mathrm{~cm}$ compr., até $1 \mathrm{~cm}$ larg. na base. Inflorescência paniculada, composta de muitas espigas de 2-4 flores. Sépalas vermelhas, até $13 \mathrm{~mm}$ compr., unidas na base, separadas no ápice, lanceolaclas, agudas, não mucronadas, subcoriáceas e obtusamente carinadas, com escamas no dorso, simétricas; P'étalas róseas.

Material examinado: Butantã, 24.X.1917, F. C. Hoehnes. n. (SP 768); Pirajussara, 29.IX.1921, A. Gehrt s. n. (SP 5763); 21.IX.1930, A. Gehrt s. n. (SPF 10189); Reserva da CUASO, 01.IX.1994, R. Dislich 108, R. Dislich 109; 29.IX.1994, R. Dislich 128.
Fenologia: na Reserva, encontrada em flor e fruto em setembro.

Distribuição geográfica: Paraguai, Uruguai, Argentina, MG, DF, RJ, SP, PR, SC e RS (Reitz 1983, Wanderley \& Mollo 1992).

Rara na Reserva, foram encontrados apenas 2 indivíduos, sobre o tronco de árvores, ca. $5 \mathrm{~m}$ de altura. Típica epífita "atmosférica”, não é capaz de acumular muita água entre as folhas devido a seu tamanho reduzido, suas raízes tem função única de fixação e as folhas são cobertas por escamas. Muito parecida com Tillandsia stricta, mas de folhas de verde mais claro e de consistência menos firme, decaindo quando morrem.

Tillandsia recurvata (L.) L., Sp. Pl. ed. 2. 410. 1762.

Folhas dísticas; lâmina linear, cilíndrica, $3-17 \mathrm{~cm}$ compr., 0,5-2 mm diâm. Inflorescência simples, 1-2(5)floral; sépalas lanceoladas, normalmente agudas, 4-9 $\mathrm{mm}$ compr., glabras; pétalas palidamente violáceas ou brancas.

Material examinado: Cidade Universitária, Jardim do Depto. de Botânica do IBUSP, 15.VIII.1994, F. R. Lopes \& R. Suzuki 11 (SPF 107860); Pirajussara, 22.I.1924, $A$. Gehrt s. n. (SP 12379); Reserva da CUASO, V.1993, $R$. Dislich 10.

Fenologia: na Reserva e arredores encontrada em fruto em maio e junho.

Distribuição geográfica: PA, PB, RN, PE, AL, BA, MG, RJ, SP, PR, SC e RS. Desde o sul dos EUA, através da América Central até a Argentina (Reitz 1983).

Na Reserva é rara, tendo sido encontrada sobre árvore isolada perto da borda. Nos jardins do Instituto de Biociências ocorre como epífita formando tapetes sobre o tronco de árvores ou em râmulos finos e também, raramente, como rupícola. É típica epífita "atmosférica", apresentando raízes com função exclusiva de fixação.

Tillandsia stricta Sol. in Sims, Bot. Mag. 37: t.1529. 1813.

Folhas em grande número, em densa roseta; lâmina estreitamente triangular, até $13 \mathrm{~cm}$ compr., $8 \mathrm{~mm}$ larg. na base. Inflorescência simples, com 10-20 flores, espiciforme. Sépalas róseo-claras, membranáceas, transparentes, de $11 \mathrm{~mm}$ compr., glabras, igualmente concrescidas até $4 \mathrm{~mm}$ da base, ovado-lanceoladas e agudas; pétalas azuis passando a roxas.

Material examinado: Butantã, 31.VIII.1917, F. C. Hoelne s. n. (SP 472); 30.VIII.1946, A. B. Joly s. n. (SPF 16765); Pinheiros, 21.VIII.1930, A.Gehrt s. n. (SPF 10286); Pira- 
jussara, 17.VIII.1929, A. Gehrt s. n. (SP 24160); Reserva da CUASO, 17.V.1994, R. Dislich 93; 02.IX.1994, $R$. Dislich 113; 16.IX.1994, R. Dislich 127.

lenologia: Observada em flor em setembro. No sul do Brasil, floração de junho a março e coletada em fruto no mês de julho (Reitz 1983).

Distribuição geográfica: BA, ES, MG, RJ, SP, PR, SC e RS. Venezuela, Trinidad, Guiana, Suriname, Paraguai, Uruguai, norte da Argentina (Reitz 1983).

Esta espécie é representada por Tillandsia stricta var. stricta, a variedade típica. Foi encontrado um indivíduo sobre árvore cultivada, muito próximo à borda da Reserval, e outros dois na mesma região de Tillandsia geminiflora. Ocorre também nos arredores da Reserva, tanto nos jardins do Instituto de Biociências quanto na Rua do Matão, sempre como epífita, às vezes formando colônias. É outra epífita atmosférica, ainda que maior que T. recurvata e com folhas em roseta, porém estreitas demais para acumularem água em quantidade. Muito parecida com T. geminiflora, possui folhas de verde mais escuro e consistência mais firme, mantendo a posição ereta mesmo depois de mortas.

\section{Vriesea Lindl.}

Vriesca gigantea Gaudich., Atl. Voy. Bonite. t. 70. 1846.

Ervas epífitas. Folhas 30-40, em roseta; bainha grande, castanha; lâmina ligulada, mucronada, 0,40-0,60 m compr., 10-15 cm larg., margem lisa. Escapo com bráct.eas muito numerosas, suberetas, agudas. Inflorescência paniculada, até $2,5 \mathrm{~m}$ compr., subpiramidada ou suboval, composta de ramos 5-15-florais. Flores dísticas ou secundas, campanuladas, $50-60 \mathrm{~mm}$ compr., pediccladas; sépalas verdes, formando um tubo; pétalas amarelo-claras, ca. $5 \mathrm{~mm}$ mais longas que as sépalas, recurvas na antese, com 2 lígulas concrescidas; ovário súpcro; óvulos longo-caudados. Fruto cápsula. Sementes com cauda no ápice e pêlos na base.

Material examinado: Reserva da CUASO, 24.VII.1994, R. Dislich 101.

Fenologia: Não observada em estado fértil.

Distribuição geográfica: ES, RJ, SP, PR, SC e RS (Reitz 1983).

Relativamente abundante em uma determinada região no interior da Reserva, a mesma em que ocorrem Tillandsia geminiflora e $T$. stricta, mas não observada fora dessa região ou fora da Reserva. Ocorre apenas em grandes alturas (acima de $7 \mathrm{~m}$ ), como cpífita verdadeira. É, em conjunto com Philodendron bipinnatifidum, a epífita de maior porte na Reserva, comumente formando rosetas de mais de um metro de diâmetro.

\section{CACTACEAE Juss.}

Plantas suculentas, terrestres, rupícolas ou epífitas. Estípulas ausentes. Folhas ausentes ou raramente presentes, alternas, simples. Flores solitárias ou raramente em cimeiras, monóclinas, perianto constituído de segmentos petalóides em várias séries espiraladas; estames numerosos; ovário ínfero ou raramente súpero, unilocular, óvulos geralmente numerosos. Fruto baga.

Bibliografia: Britton e Rose (1963), Scheinvar (1985), Lombardi (1991), Barthlott e Taylor (1995).

\section{Rhipsalis Gaertn.}

Ervas epífitas ou rupícolas, áfilas. Artículos cilíndricos ou aplanados, às vezes com costelas marcadas, angulados ou alados. Aréolas providas de escama basal diminuta, lã, pêlos e cerdas. Flores $6-25 \mathrm{~mm}$ compr., actinomorfas; pericarpelo e tubo sem aréolas; segmentos do perianto livres. Fruto baga globosa a elipsóide ou turbinada, suculenta; semente negra, ca. $1 \mathrm{~mm}$ compr.

Chave para identificação das espécies de Rhipsalis 1. Artículos trígonos ou tetrágonos

1'. Artículos cilíndricos.

2. Artículos homomórficos .................R. grandiflora 2'. Artículos heteromórficos ......................... R. teres

Rhipsalis grandiflora Haw., Suppl. Pl. Succ. 83. 1819. Rhipsalis hadrosoma Lindb., Monatsschr. Kakt. 6: 96. 1896.

Artículos cilíndricos, homomórficos, 4-7 mm diâm. Aréolas com escama basal triangular, às vezes com uma cerda. Flores laterais, às vezes terminais, $13-18 \mathrm{~mm}$ diâm.; Pericarpelo emerso, globoso, glabro; segmentos perianto ca. 15, branco-cremosos, às vezes avermelhados no ápice. Fruto baga subglobosa, glabra, brancoleitosa a rósea.

Material examinado: Butantan, 21.VIII.1917, F. C. Hoelne s. n. (SP 435); Reserva da CUASO, 13.V.1993, R. Dislich 1; 28.I.1994, R. Dislich 28; 03.II.1994, R. Dislich 50; 01.IX.1994, R. Dislich 106; 02.IX.1994, R. Dislich 110.

Fenologia: encontrada florescendo em setembro e com frutos em janeiro, fevereiro, maio e junho. Frutos verdes em setembro e outubro. 
Distribuição geográfica: W de RJ, SP, PR e SC (Barthlott \& Taylor 1995).

Esta planta ć a cactácea epífita mais comum na Reserva, ocorrendo em toda a área da mata, e também espontancamente nos seus arredores, jardins do Instituto de Biociências, e em áreas arborizadas na cidade de São Paulo, sempre como epífita. O exemplar do herbário SP foi anotado por Nigel Taylor como Rhipsalis hadrosoma Lindb.

Rhipsalis teres (Vell.) Steudel, Nom., ed. 2, 2: 449. 1841. Rhipsalis capilliformis F.A.C.Weber, Rev. Hort. (Paris) (i4: 425. 1892.

Rhipsalis heteroclada Britton \& Rose, Cact. 4: 224. 1923.

Artículos cilíndricos, heteromórficos, os basais várias vezes mais longos que os apicais, $2-4 \mathrm{~mm}$ diâm. Aréolas com escama basal triangular, às vezes com uma cercla. Flores laterais a terminais, ca. $8 \mathrm{~mm}$ diâm.; pericarpelo emerso, subgloboso, glabro; segmentos do perianto 8 , os exteriores verdes, os interiores brancos, esverdeados ou amarelados. Fruto baga globosa, glabra, branca ou vinácea.

Matterial examinado: Reserva da CUASO, 28.I.1994, $R$. Dislich 38; 03.II.1994, R. Dislich 53; 29.IV.1994, R. Dislich 74; 03.V.1994, R. Dislich 79, R. Dislich 85; 30.VIII.1994, R. Dislich 104; 08.IX.1994, R. Dislich 114, R. Dislich 115; 12.IX.1994, R. Dislich 116; 05.X.1994, R. Dislich 131.

Fenologia: em cultivo, floresceu em agosto e novembro/ dezembro. Na Reserva, flores em abril e maio.

Distribuição geográfica: MG, RJ, SP, PR, SC, RS (Scheinvar 1985, Barthlott \& Taylor 1995).

Menos comum que Rhipsalis grandiflora na Reserva, ocorre $\mathrm{cm}$ toda a área da mata. Pode ser encontrada sob) duas formas básicas, dependendo das condições ambientais: (1) forma capilliformis (F.A.C.Weber) Barthlott \& N.P.Taylor, de sombra, a pequenas alturas, sempre pendente e muito ramificada, apresentando coloração verde-escura; (2) forma heteroclada (Britton \& Rose) Barthlott \& N.P.Taylor, de sol, usualmente em grandes alturas, ereta, menos ramificada e de cor verde-clara. Scheinvar (1985) considerou as duas formas como espécies distintas. Sempre como epífita, também loi observada nos arredores da Reserva e sobre árvores nas ruas da cidade de São Paulo.

Rhipsal lis trigona Pfeiff., Enum. cact. 133. 1837.

Artículos trígonos, homomórficos, com as arestas de um artículo alternadas com a superfície plana do artículo seguinte, ca. $10 \mathrm{~mm}$ larg. Aréolas com escama basal crassa, auricular, com cerdas numerosas na épo- ca da floração. Flores laterais, ca. 6 mm diâm.; pericarpelo imerso na aréola, globoso, glabro, com tubérculos longitudinais; segmentos do perianto ca. 11, esbranquiçados ou avermelhados. Fruto baga globosa, imersa na aréola, glabra, vermelha.

Material examinado: Butantan, 03.VI.1920, F. C. Hoelme s. n. (SP 4163); Mata da Reserva da Cidade Universitária, 30.XI.1993, D.C. Zappi \& N.P. Taylor s. n. (SPF 85788); 28.I.1994, R. Dislich 39.

Fenologia: encontrada em flor em maio, no jardim do Departamento de Botânica.

Distribuição geográfica: S de SP, PR, E de SC (Barthlott \& Taylor 1995).

É a cactácea menos comum na Reserva. Ocorre sempre como epífita, a alturas maiores que $5 \mathrm{~m}$, e é mais facilmente encontrada nas proximidades do riacho. Também ocorre nos jardins do Instituto de Biociências.

\section{MORACEAE Link.}

Árvores e arbustos, raramente ervas. FOLHAS alternas, dísticas ou espiraladas, simples; estípulas laterais ou intrapeciolares comumente envolvendo a gema terminal. Inflorescências em sicônios, racemos ou espigas, raramente em cimeiras. Flores diclinas, (1-)45(-8) sépalas, sem pétalas; Estames 1-4; ovário súpero a ínfero, 1-locular, 1-ovulado. Fruto drupa ou aquênio.

Bibliografia: Carauta (1989), Rossi (1994).

As espécies desta família que ocorrem na área, todas do mesmo gênero, são exemplos típicos de hemiepífitas primárias, germinando sobre o forófito e depois alcançando o solo por meio de raízes. São também chamadas de estrangulantes porque, uma vez fixando-se no solo, as raízes se ramificam e espessam, podendo levar à morte da árvore-suporte. Todas ocorrem como árvores dentro da Reserva (Rossi 1994).

Para as espécies desta família não foram feitas observações sobre a fenologia reprodutiva, uma vez que, na condição epifítica, as plantas ainda são jovens demais para a produção de flores e frutos.

\section{Ficus L.}

Árvores lactescentes. Estípula envolvendo a gema terminal. Folhas alternas, inteiras, raramente denteadas ou lobadas. Inflorescência tipo sicônio globoso e carnoso, com poro apical fechado por brácteas imbricadas, axilar, solitário, geminado ou agrupado em ra- 
cemos. Fruto aquênio, no interior do sicônio desenvolvido.

Chave para as espécies de Ficus

1. Nervação pouco nítida na face adaxial ... F. microcarpa

1'. Nervação nítida em ambas as faces.

2. Mais de 10 pares de nervuras laterais .. F. insipida 2'. Menos de 8 pares de nervuras laterais.

3. Estípulas, pecíolos e ramos jovens pubérulos F. hirsuta

3'. Estípulas, pecíolos e ramos jovens glabros ........ F. Iuschnatiana

Ficus hirsuta Schott in Spreng. Syst. 4 Cur. Post. 414. 1827.

Ficus organensis (Miq.) Miq., Ann. Mus. Bot. Ludg. Bat. 3: 229. 1867.

Estípula $8 \mathrm{~mm}$ compr., pubérula, esverdeada. Pecíolo 4-14 mm compr., pubérulo; Lâmina foliar cartácea, glabra ou pubescente, lanceolada, ovada, elíptica ou obovada, 2-5,5 cm compr.; base cuneada, arredondada ou emarginada, ápice agudo; nervação 5-9 pares de nervuras laterais.

Material examinado: Reserva da CUASO, 23.VI.1993, $R$. Dislich 12; 29.I.1994, R. Dislich 41; 25.X.1994, R. Dislich 149.

Distribuição geográfica: MG, RJ, SP, PR, SC, RS (Carauta 1989).

Menos freqüente que Ficus luschnatiana na Reserva, é encontrado mais facilmente nas áreas intermediárias entre o riacho e a borda. Também ocorre nos arredores da Reserva como hemiepífita e rupícola. A espécie é referida para a mata por Rossi (1994).

Ficus insipida Willd., Sp. pl. 4(2): 143. 1806.

Estípula 3-12 cm compr., glabra, esverdeada. Pecíolo 1,5-6 cm compr., glabro; Lâmina foliar cartácea, glabra ou glabrescente, elíptica, oblonga ou ovada, $5-30 \mathrm{~cm}$ compr; base arredondada a obtusa, ápice agudo ou curtamente acuminado; nervação 5 mais $10-20$ pares de nervuras laterais (às vezes em maior número), levemente proeminentes nas duas superfícies.

Material examinado: Reserva da CUASO, 31.V.1994, $R$. Dislich 96; 24.VIII.1994, R. Dislich 102; 15.IX.1994, R. Dislich 119; 18.X.1994, R. Dislich 139; 19.X.1994, R. Dislich 140, 141.

Distribuição geográfica: América Central até a Argentina. No Brasil ocorre em todas as regiões (Carauta 1989).

Encontrada várias vezes na condição epifítica, principalmente sobre Cyathea delgadii Sternb. (samambaia- çu), como planta jovem, de até $50 \mathrm{~cm}$ de altura, e sem conexão com o solo. O subgênero a que pertence esta espécie (Pharmacosycea Miq.) não apresenta, comumente, representantes hemiepifíticos (Carauta 1989). É possível que seja hemiepífita apenas acidental, normalmente germinando no solo (plantas jovens são comumente encontradas no chão). Não é, no entanto, efêmera: foram observados indivíduos sobrevivendo durante mais de um ano. Como adulta, Ficus insipida apresenta algumas das árvores mais imponentes presentes na mata, possuindo raízes tabulares.

Ficus luschnatiana (Miq.) Miq., Ann. Mus. Bot. Ludg. Bat. 3: 298. 1867.

Ficus enormis (Mart. ex Miq.) Miq., Ann. Mus. Bot. Ludg. Bat. 3: 98. 1867.

Ficus pertusa L.f., Suppl. 442.

Ficus citrifolia P.Miller, Gard. Dict., ed. 8, Ficus no. 10, 1768.

Estípula 0,5-2,5 cm compr., glabra, avermelhada ou mais raramente esverdeada. Pecíolo $2-9 \mathrm{~cm}$ compr., glabro; Lâmina foliar cartácea, glabra, elíptica, oblonga, oboval, oboval-oblonga ou oval-oblonga, $5-19 \mathrm{~cm}$ compr.; base de truncada ou emarginada a aguda, ápice agudo ou acuminado; nervação 3-5 mais 4-12 pares de nervuras laterais, de coloração muito clara.

Material examinado: Reserva da CUASO, 01.II.1994, $R$. Dislich 49; 18.V.1994, R. Dislich 95; 01.IX.1994, R. Dislich 107; 12.IX.1994, R. Dislich 117; 15.IX.1994, R. Dislich 120-124; 11.X.1994, R. Dislich 135; 25.X.1994, R. Dislich 150-152; 08.VI.1995, R. Dislich 169; 29.VI.1995, R. Dislich 174; 27.IX.1995, R. Dislich 179.

Distribuição geográfica: ocorre em todas as regiões do Brasil, embora haja maior concentração no Sudeste (Carauta 1989).

É a espécie de Ficus mais comumente encontrada na condição epifítica dentro da Reserva. Ocorre tanto no interior da mata quanto nas bordas. Nos jardins do Instituto de Biociências ocorre como epífita e rupícola. Também aparece como rupícola na borda da mata. Muitos indivíduos sobre árvores já apresentam conexão com o solo. É raro, porém, encontrar-se um indivíduo que tenha a raiz fixada ao solo já espessa (acima de $5 \mathrm{~cm}$ de diâmetro). Como árvore adulta, ocorre no interior da mata, com sua copa fazendo parte do dossel (Rossi 1994).

Ficus microcarpa L.f., Suppl. pl. 442. 1781.

Estípula $1 \mathrm{~cm}$ compr., glabra, esverdeada. Pecíolo ca. $7 \mathrm{~mm}$ compr., glabro; Lâmina foliar coriácea, glabra, elíptico-aguda, 4,0-6,0 cm compr.; base aguda a obtusa, ápice acuminado; nervação pouco nítida. 
Matcrial examinado: Reserva da CUASO, 28.VII.1995, R. Dislich 176.

Distribuição geográfica: Ásia e Australásia (Carauta 1989).

Foi encontrado um indivíduo pequeno, a $11 \mathrm{~m}$ de altura. Pode também ser encontrada como epífita sobre árvores na calçada e em frestas nas ruas de São Paulo. Também ocorre dentro da Reserva como árvore adulta, provavelmente introduzida. É a espécie exótica de Ficus mais cultivada no Brasil (Carauta 1989).

\section{ORCHIDACEAE Juss.}

Ervas epífitas ou terrestres. Folhas alternas ou raramente opostas ou verticiladas, às vezes rosuladas ou reduzidas a escamas, simples; estípulas ausentes. Flores isoladas ou em racemo, espiga ou panícula, monoclinas ou raramente diclinas; perianto de 6 tépalas em 2 sćrics, com uma delas modificada em labelo; estames 1-2 adnatos ao estilete, formando um ginostêmio ou coluna; ovário ínfero, 1(3)-locular, óvulos muito numerosos. Fruto cápsula deiscente.

Bibliografia: Kränzlin (1922, 1926), Schlechter e Hochne (1926), Hoehne (1945,1949), Pabst e Dungs (1977), Barros (1983).

Joly (1950) citou duas espécies da família para a mata, na sua interface com o brejo, sem porém dizer se eram epílitas: Galeandra beyrichii Rchb.f., que, segundo Barros (1983), é terrestre e Epidendrum ellipticum Grah., que, segundo Fábio de Barros (comunicação pessoal), ocorre como epífita. Nenhum outro pesquisador apontou orquídeas na Reserva.

Durante este trabalho, foram encontradas 6 espécies clesta família na mata. Outra Orchidaceae, de folhas dísticas, semelhante a Epidendrum, foi encontrada sobre árvore nos jardins do Instituto de Biociências.

Chave para os gêneros de Orchidaceae

1. Presença de pseudobulbos.

2. Follhas carnosas, isoladas Oncidium

2'. Iolhas não carnosas, dísticas.

3. Pseudobulbos arredondados; bases das folhas formando um pseudocaulc .............. Polystachya

3'. Pseudobulbos compressos; sem pseudocaule Notylia

1'. Ausência de pseudobulbos.

4. Folhas em roseta .................................. Eurystyles

4'. Folhas dísticas, distanciadas.

5. Folhas com ápice assimetricamente emarginado . Campylocentrum

5'. Folhas com ápice obtuso Epidendrum

\section{Campylocentrum Benth.}

Campylocentrum linearifolium Schltr. ex Mansf. in Fedde, Repert. 24: 246. 1928.

Planta epífita; crescimento monopodial, caule alongado. Folhas alternas, dísticas, planas, lâmina 6,0-8,5 $\mathrm{cm}$ compr., ápice assimetricamente emarginado; bainha 1,2-1,7 cm compr. Pseudobulbos ausentes. Inflorescência simples, em racemos axilares, com 6-9 flores alternas e dísticas, eixo 7-13 mm compr. Flores com cálcar de 2-3 mm compr.; polínias cartilaginosas, com estipe e viscídio. Frutos cilíndricos.

Material examinado: Reserva da CUASO, 12.XII.1995, R. Dislich 182.

Fenologia: encontrado em fruto em maio. Em cultivo, floresceu em novembro e dezembro.

Distribuição geográfica: BA, RJ, SP, PR, MG, GO (Pabst \& Dungs 1977).

É rara na mata, tendo sido encontrados representantes desta espécie apenas sobre uma árvore, à direita do riacho, próximo ao lago. Na mesma árvore também foram encontrados representantes de outras espécies de orquídeas. Epífita verdadeira.

\section{Epidendrum L.}

Epidendrum sp.

Planta epífita; crescimento monopodial, caule alongado. Folhas carnosas, alternas, dísticas, planas, oblongas, verdes; ápice obtuso. Pseudo bulbos ausentes.

Material examinado: planta viva, não herborizada.

Fenologia: não encontrado em floração.

\section{Distribuição geográfica:?}

Encontrado apenas um indivíduo jovem, a 6 metros de altura, sobre Ficus insipida de grande porte, na beira do riacho. Coletado e mantido em cultivo, não chegou a florescer. É possível que se trate do Epidendrum ellipticum Graham, já citado para a Reserva por Joly (1950).

\section{Eurystyles Wawra}

Eurystyles cotyledon Wawra, Oestr. bot. Zeitschr. 12: 233. 1863.

Planta epífita. Folhas em roseta, ereto-patentes, oboval-oblongas, atenuadas para a base em pseudo-pecío- 
lo cunciforme, margens ciliadas, $1,5-4 \mathrm{~cm}$. compr. Pseudobulbos ausentes. Inflorescência com haste delgada, de 1-3 cm compr.; espiga floral curta, com 5-18 flores; brácteas ovais, pubérulas, margens ciliadas, $7-10 \mathrm{~mm}$ compr: Flores pequenas em relação às brácteas, ocultats entre elas, brancas.

Matcrial cxaminado: Reserva da CUASO, 24.VIII.1994, R. Dislich 100; 01.XI.1994, R. Dislich 156.

Fenologia: Em cultivo, floresceu em março. Encontrada com fruto verde em junho. Segundo Hoehne (1945), floração de abril a maio.

Distribuição geográfica: Serra do Mar, no Brasil Meridional e alguns pontos no interior da mesma latitude. SP, RJ C PR (Hoehne 1945).

Epílita verdadeira formando rosetas de ca. $3 \mathrm{~cm}$ de diâmctro, portanto bastante inconspícua, ainda que, em alguns casos, possam se formar colônias grandes, com cerca de 100 indivíduos. Esta espécie foi encontrada sobre 3 árvores diferentes no interior da mata, apesar do pequeno tamanho, o que indica não ser uma planta rara, pelo menos em comparação com outras orquídeas da Rescrva.

\section{Notylia Lindl.}

Notylia longispicata Hochne \& Schltr., Arch. Bot. São Paulo 1(3): 280. 1926.

Planta epífita, simpodial. Pseudobulbos compressos. Folhas dísticas, cartáceas, oblongas, apenas com a nervura central proeminente, 4,0-12,0 cm compr. Inflorescência lateral $\mathrm{cm}$ racemo longo. Flores com labelo lanceolado, unguiculado, não articulado com a coluna, mais curto que as sépalas laterais ou do mesmo compr. que clas; polínias duas, cartilaginosas, viscídio menor que a estipe.

Matcrial examinado: Cidade Jardim, 29.I.1942, W. Hoehne s. n. (SPF 1071); Reserva da CUASO, 17.I.1996, $R$. Dislich 181 .

Fenologia: cm cultivo, floresceu em janeiro. Fruto verde em julho.

Distribuição geográfica: SP (Pabst \& Dungs 1977).

É a orquídea mais freqüente na mata e epífita verdadeira. Segundo Hoehne (1949), as espécies deste gênero são conhecidas vulgarmente como "parasitas de capocira", pois são das primeiras que aparecem em malas secundárias.

\section{Oncidium Sw.}

Oncidium pumilum Lindl., Bot. Reg. 11, t. 920. 1825.

Planta epífita, simpodial. Folhas carnosas, oblongolanceoladas, apenas com a nervura central proeminente, verdes, base atenuada. Pseudobulbos cilíndricos, lisos, 1-foliados, 0,3-0,5 cm compr. Inflorescência lateral, paniculada. Flores de labelo não articulado com a coluna, livre dela em sua extensão, reto, patente desde a base, séssil, 0,2-0,4 cm compr., 3-lobado, lobos laterais tão longos ou mais longos que o lobo central; coluna alada junto ao estigma; antera apical; polínias 2, cartilaginosas; viscídio menor que a estipe.

Material examinado: Reserva da CUASO, 28.X.1994, $R$. Dislich 155; 10.II.1995, R. Dislich 163.

Fenologia: em cultivo, floresceu em fevereiro. Segundo Schlechter (1915), a floração se dá de abril a maio.

Distribuição geográfica: PA, BA, ES, RJ, SP, PR, SC, RS, MG, DF, GO, MT, Uruguai, Paraguai, Argentina (Schlechter 1915, Kränzlin 1922, Pabst \& Dungs 1977). Segundo Hoehne (1949), ocorre também nas matas ciliares dos maiores tributários do Rio Negro.

Epífita verdadeira, tem folhas carnosas que servem como reservatório de água. Foi encontrada na mesma árvore que Campylocentrum linearifolium e em mais duas outras.

É das primeiras, junto com espécies de Gomesa e Notylia, que surgem nas capoeiras, ocorrendo também nas matas mais secas de São Paulo e de Minas Gerais, possuindo perfume muito intenso e agradável (Hoehne 1949).

\section{Polystachya Hook.}

Polystachya estrellensis Reichb.f., Linnaea 25: 231. 1852. Planta epífita, simpodial. Pseudobulbos homoblásticos, arredondados. Folhas dísticas, coriáceas, lineares, 3,5-14,0 cm compr., bases formando um pseudocaule. Inflorescência terminal em panícula. Flores com sépalas laterais unidas ao pé da coluna, formando um mento, labelo 3-lobado, com lobo central denteado na margem; cálcar ausente; polínias 4 , cartilaginosas, caudículo e estipe presentes.

Material examinado: Reserva da CUASO, 12.IX.1994, $R$. Dislich 118; 01.XII.1994, R. Dislich 158; 10.II.1995, R. Dislich 164.

Fenologia: encontrada em fruto em setembro. Em cultivo, floresceu em fevereiro. 
Distribuição geográfica: SP, PR, MT, MG, RS, Suriname (Kränzlin 1926, Hoehne 1949).

A maior espécie de orquídea da Reserva, foi encontracla apenas duas vezes no interior da mata, como epífita verdadeira.

Segundo Hoehne (1949), esta espécie é uma das maiores do gênero e, assim como espécies de Notylia, é conhecida como "parasita da capoeira", por aparecer com maior freqüência nas matas ralas e sobre árvores isoladas, com córtex mais suberoso e seco.

\section{PIPERACEAE C. Agardh}

Arvoretas, arbustos ou ervas suculentas, terrestres ou cpífitas. Folhas alternas, raramente opostas ou verticiladlas, simples; estípulas presentes ou ausentes. Inl'orescência cm espiga ou racemo. Flores monóclinas ou clíclinas, sem perianto; estames 1-10; ovário súpero, 1-locular, 1-ovulado. Fruto drupa.

Bibliografia: Guimarães et al. (1984), Yuncker (1974).

\section{Peperomia Ruiz \& Pav.}

Pepcromia urocarpa Fisch. \& C.A.Mey., Index Sem. Hort. Petrop. 4: 42. 1837.

Planta herbácea, carnosa, rastejante, pubescente. Folhas alternas, pecíolos 2,5-4 cm compr.; lâmina membranácea, arredondada, ovada, de base truncada, arredonclada ou cordada, ápice agudo ou obtuso, 2,5-4,5 cm compr. Espigas axilares ou terminais, solitárias ou subgeminadas, bracteadas, pedunculadas. Drupas rostraclas, ca. 1,2 $\mathrm{mm}$ compr.

Material cxaminado: Butantan, 07.VII.1917, F. C. Hoehne s. n. (SP 332); Reserva da CUASO, 22.VIII.1994, $R$. Dislich 98 .

Fenologia: coletada em flor em agosto.

Distribuição geográfíca: RN, BA, DF, MG, ES, RJ, SP, PR, SC: e RS (Guimarães et al. 1984).

Rclativamente rara, encontrada como epífita na base de troncos de grandes árvores ou como erva terrestre, sempre em locais sombreados e úmidos, no interior da mala.

\section{Chave de identificação das espécies através de} características vegetativas

I. P'lantas áfilas.

2. Secção transversal do caule triangular

2'. Secção transversal do caule circular. Rhipsalis trigona

3. Artículos basais com até $4 \mathrm{~mm}$ de diâmetro, várias vezes mais longos que os apicais; estes com até $2 \mathrm{~mm}$ de diâmetro ......... Rhipsalis teres 3'. Artículos todos aproximadamente do mesmo tamanho, os basais com até $7 \mathrm{~mm}$ e os apicais com $4 \mathrm{~mm}$ de diâmetro .... Rhipsalis grandiflora

1'. Plantas com folhas.

4. Folhas digitadas, pinatífidas, pinatissectas ou pinadas.

5. Folhas digitadas Schefflera actinophylla

5'. Folhas pinatífidas, pinatissectas ou pinadas.

6. Folhas cordado-sagitadas Philodendron bipinnatifidum

6'. Folhas com outro formato.

7. Pinas ou segmentos menores en direção à base da lâmina.

8. Lâmina densamente recoberta por pelos ........... Polypodium hirsutissimum

8'. Lâmina glabra ... Blechnum binervatum

7'. Pinas ou segmentos de aproximadamente o mesmo comprimento em direção à base da lâmina.

9. Folhas pinadas, raque desnuda

Polypodium triseriale

9'. Folhas pinatissectas ou pinatifidas, raque coberta pela lâmina.

10. Nervura central das pinas ou segmentos oblíqua em relação à raque ... Polypodium pleopeltifolium

10'. Nervura central das pinas ou segmentos perpendicular à raque.

11. Segmento apical maior que os laterais ...... Polypodium aureum

11'. Segmento apical menor que os laterais

Polypodium catharinae

4'. Folhas simples e sem recortes ou cordado-sagitadas.

12. Plantas lenhosas, com látex.

13. Nervação pouco nítida na face adaxial ..... Ficus microcarpa

13'. Nervação nítida em ambas as faces.

14. Mais de 10 pares de nervuras laterais .... Ficus insipida

$14^{\prime}$. Menos de 8 pares de nervuras laterais.

15. Estípulas, pecíolos e ramos jovens pubérulos .............. Ficus hirsuta

15'. Estípulas, pecíolos e ramos jovens glabros ... Ficus luschnatiana

12'. Plantas herbáceas, sem látex.

16. Folhas congestas, em roseta.

17. Margem da lâmina foliar lisa.

18. Folhas maiores da roseta com até $4 \mathrm{~cm}$ de comprimento

Eurystyles cotyledon

18'. Folhas maiores da roseta com mais de $8 \mathrm{~cm}$ de comprimento.

19. Base da lâmina foliar com mais 
de $10 \mathrm{~cm}$ de largura .... Vriesea gigantea

19'. Base da lâmina foliar com até $1 \mathrm{~cm}$ de largura.

20. Folhas mortas pendentes da base da roseta; folhas vivas, quando úmidas, verde-claras

Tillandsia geminiflora

20'. Folhas mortas na mesma posição das vivas, decurvas; folhas vivas, quando úmidas, verde-escuras Tillardsia stricta

17'. Margem da lâmina foliar espinosa.

21. Cicatriz na face abaxial da folha, na junção entre bainha e lâmina (material seco) Aechmea nudicaulis

21'. Folhas sem cicatriz na face abaxial.

22. Bainha foliar mais estreita que a lâmina Billbergia zebrina

22'. Bainha foliar mais larga que a lâmina.

23. Espinhos foliares conspícuos, escuros; relação entre largura e compri- mento da lâmina foliar maior que 1:20 Aechmea bromeliifolia

23'. Espinhos foliares pouco desenvolvidos, claros; relação entre largura e comprimento da lâmina foliar menor que $1: 40$...... Acchmea distichantha

16'. Folhas laxas.

24. Folhas cordado-sagitadas.

25. Catáfilos apicais e face abaxial das folhas róseo-avermelhados

Philodendron erubescens

25'. Catáfilos apicais e face abaxial das folhas verde-claros ......... Philodendron imbe

24'. Folhas não sagitadas.

26. Pecíolo alado ... Philodendron propinquum

26'. Pecíolo sem alas ou folha séssil.

27. Venação reticulada, conspícua.

28. Folhas de base obtusa ou truncada.

29. Folhas sésseis ou sub-sésseis .... Microgramma vacciniifolia

29'. Folhas pecioladas

Peperomia urocarpa

28'. Folhas de base atenuada.

30. Folhas com mais de $30 \mathrm{~cm}$ de comprimento

......... Campyloneurum major

30'. Folhas com até $15 \mathrm{~cm}$ de comprimento
... Microgramma squamulosa

27'. Venação paralela ou inconspícua. 31. Folhas lineares, com largura até $2 \mathrm{~mm}$ Tillandsia recurvata 31'. Folhas não lineares, com largura maior que $5 \mathrm{~mm}$.

32. Nervura central negra ......... Pleopeltis astrolepis

32'. Nervura central verde.

33. Presença de pseudobulbos.

34. Folhas carnosas, isoladas

.. Oncidium pumilum

34'. Folhas não carnosas, dísticas.

35. Pseudobulbos arredondados; bainhas das folhas formando um pseudocaule ...... Polystachya estrellensis

35'. Pseudobulbos compressos; sem pseudocaule

Notylia longispicata

33'. Ausência de pseudobulbos.

36. Folhas com ápice assimetricamente emarginado Campylocentrum linearifolium

36'. Folhas com ápice obtuso ... Epidendrumsp.

\section{Discussão e conclusões}

Antes da realização do presente levantamento existiam vários motivos para se acreditar em uma flora epifítica pouco desenvolvida na Reserva, como o fez Rossi (1994). A autora, embora não tenha estudado o grupo em detalhes, afirmou que "a área é relativamente pobre em epífitas, (...) em [termos de] diversidade específica", considerando esta informação como uma evidência da grande interferência sofrida no passado pela vegetação ali existente.

Pelo menos quatro características da vegetação da Reserva nos levariam a esperar um número pequeno de espécies de epífitas: (1) as informações de que dis- 
pomos sobre o estádio sucessional da mata na área; (2) a sua condição de "ilha" de área pequena e cercada por ambiente urbano; (3) a falta de proteção da Reserva durante a maior parte da sua história; (4) os altos níveis de poluição atmosférica encontrados em uma cidade como São Paulo.

Segundo Budowski (1965), matas secundárias apresentam número relativamente pequeno de espécies epilíticas. Isto se deve principalmente à lentidão, por parte dessas plantas, na colonização de novas áreas. A condição secundária da vegetação da Reserva, vista como um todo, leva assim à expectativa de uma flora de epífitas reduzida. É possível, porém, que pequenas manchas de vegetação $\mathrm{cm}$ melhor estado de conservação dentro da Reserva tenham contribuído para a manutenção de parte da riqueza de epífitas original do local.

A fragmentação de hábitats tem efcito negativo sobre a riqueza de espécies de uma determinada área (Wilcox \& Murphy 1985). Isto ocorre por alguns motivos. Un cleles se deve a um cfeito de amostra: dentro de um fiagmento da área original podem não estar representadlas todas as espécies. As mais raras têm grandes chancès de não ocorrer. Além disso, há uma tendência de diminuição do número de espécies em um fragmento, com o passar do tempo, pelo desaparecimento de espécics que exigem uma área mínima maior que a disponível para a sua sobrevivência. O desaparecimento de detcrminadas espécies pode, ainda, inviabilizar a sohrevivencia de outras. Este seria o caso, por exemplo, de plantas que possucm polinizadores e/ou dispersores específicos. Estes efeitos são inversamente proporcionais ao tamanho da área do fragmento.

Segundo Meguro et al. (1979a) o isolamento da Reserva limita o processo de sucessão ecológica ali, permitindo seu enriquecimento apenas através de espécies cultivadas que ocorrem ao redor.

A falta de proteção efetiva à vegetação da Reserva antes de 1979, quando esta foi cercada, impedindo a entrada de pessoas, pode ter tido efeitos negativos sobre a vegetação epifítica. Muitas epífitas, em especial as Orchidaceae e Bromeliaceae, têm grande valor ornamental, c são facilmente retiráveis das árvores.

A grande dependência nutricional de muitas epífilas com relação à água das chuvas, rapidamente absorvicla, faz com que estas plantas sejam potencialmente mais suscctívcis a efeitos deletérios da poluição atmosférica do que a vegetação terrestre. Neste sentido, níveis altos de poluição poderiam vir a prejudicar ou até mesmo extinguir localmente espécies epifíticas mais scnsívcis, mesmo antes de um efeito nítido sobre os outros componentes da vegetação.

No cntanto, uma comparação com outras floras epilíticàs conhecidas revela que o número de espécies epilíticas cncontrado na Reserva não é tão baixo quanto seria de se supor. Nesta comparação, é pertinente a inclusão do fator que provavelmente maior influência exerce sobre a diversidade de epífitas em uma determinada área: a disponibilidade hídrica (Gentry \& Dodson 1987a). O critério mais simples que se pode adotar para medir esta disponibilidade é a precipitação média anual, mensurável com certa facilidade e dado normalmente presente nas descrições de locais de estudo. Outras variáveis, como a uniformidade da distribuição da precipitação ao longo do ano, a quantidade de névoa ou neblina que atinge a vegetação e a umidade relativa do ar, também são referidas como importantes por outros autores, mas são menos facilmente medidas e/ou os dados correspondentes não são freqüentes na literatura.

Alguns dados de locais com precipitações anuais entre 1100 e $1550 \mathrm{~mm}$ : Long Point, na Austrália, possui 15 espécies epifíticas (Benzing 1990); Round Hill, na Jamaica, 10 espécies (Kelly et al. 1988); em Curitiba, PR, existem dois levantamentos distintos, o de Hertel (1950), com 98 espécies e o de Cervi et al. (1988), com 26 espécies (excluindo-se as Bromeliaceae); em Torres, RS, há 120 espécies (Waechter 1986); em Shelly Beach, Austrália, 19 espécies (Benzing 1990); Parque Nacional El Rey, Argentina, 47 espécies (Brown 1990) ; Serra do Cipó, MC, 36 espécies (Campos 1995); Santa Rosa, Costa Rica, 24 espécies (Gentry \& Dodson 1987a). Como pode ser observado, a flora epifítica da Reserva (1207 mm), com suas 37 espécies, não é nitidamente mais pobre do que as dos locais citados, com exceção de Torres e um dos levantamentos de Curitiba.

Alguns fatores contribuem para o número relativamente alto de epífitas encontrado na Reserva. A própria localização no continente americano é um deles. É documentada a maior diversidade de epífitas na América, se comparada com a África e a Australásia (Gentry \& Dodson 1987a). O endemismo neotropical de Bromeliaceae c Cactaceae tem influência nisto. O gênero Rhipsalis tem seu centro de dispersão no sul-sudeste do Brasil (Scheinvar 1985), dando também contribuição na flora da Reserva. Além disso, é possível que a mata atlântica de encosta na Serra do Mar, a menos de $30 \mathrm{~km}$ ao sul da Reserva, tenha funcionado como fonte de espécies epifíticas. Embora sua flora epífita seja pouco conhecida, a vegetação que cobre a Serra do Mar, em São Paulo, é riquíssima nessas plantas. Isto é indicado pelas condições climáticas no local, principalmente as altas precipitações e a grande freqüência de névoa úmida, decorrentes de processos orogênicos.

Uma comparação com trecho de mata atlântica se faz possível pelos conhecimentos existentes sobre a flora fanerogâmica da Ilha do Cardoso (Barros et al. 1991), no extremo sul do Estado de São Paulo. Das espécies que 
ocorrem na Reserva, seis Bromeliaceae (Aechmea distichantha, Acchmea nudicaulis, Billbergia zebrina, Tillandsia geminiflora, Tillandsia stricta e Vriesea gigantea) e três Moraceae (Ficus luschnatiana, Ficus insipidae Ficus hirsuta) são citadas também para a ilha, além de Peperomia urocarpa (Piperaceae), Rhipsalis teres (Cactaceae) e Campylocentrum linearifolium(Orchidaceae). É interessante o fato de que grande parte das Bromeliaceae da Rescrva também ocorrem na ilha, mas, com exceção de Acchmea nudicaulis, todas são de distribuição restrita ou pouco comuns na Reserva. A pequena coincidência de espécies de Araceae e Orchidaceae também é digna de nota.

Outra possibilidade de comparação se dá através das informações existentes sobre algumas famílias no Parque Estadual das Fontes do Ipiranga (PEFI), em São Paulo - SP. Em Orchidaceae (Barros 1983), são espécies cm comum Notylia longispicata, Oncidium pumilum e Polystachya estrellensis, todas coincidentemente conhecidas como sendo das primeiras a se instalar em matas secundárias. A presença dessas espécies na Reserva, aliás, pode ser considerada como mais um indicador da condição alterada da vegetação no local.

Outras espécies em comum com o PEFI são: Ficus luschnatiana (Romaniuc Neto \& Wanderley 1992), Peperomia urocarpa (Guimarães 1988), Rhipsalis teres e Rhipsalis trigona (Tamashiro \& Zickel 1991).

Ainda que o número de espécies epifíticas na Reserva seja rclativamente alto, o efeito do isolamento da área e dass perturbações sofridas pela vegetação no local fica claro quando se analisa a composição da flora, em termos clas lamílias mais importantes, a distribuição geográlica das espécies e sua distribuição espacial no interior da Reserva.

Podem ser identificados três padrões básicos de distribuição geográfica entre as epífitas da Reserva: (1) espécies exóticas, (2) espécies de ampla distribuição (neotropicais) e (3) espécies de distribuição restrita.

As espécies epífitas exóticas presentes na flora da Reserva, ainda que raras, dão suporte para a hipótese de Meguro et al. (1979a) sobre o enriquecimento da flora cla área por espécies não existentes na vegetação original. As três espécies amostradas são cultivadas nas proximidades da Reserva, como ornamentais, e são invasoras na área, estabelecendo-se espontaneamente.

As espécies de ampla distribuição, que se estendem clesde a América Central até o sul do Brasil, Argentina, Uruguai e Paraguai, são maioria na Reserva. Quase todats as Pteridophyta apresentam esse pachão, assim como várias Bromeliaceae e Ficus spp. Espécies de ampla distribuição geográfica apresentam capacidade de sobrevivência em condições ambientais muito diversificadas, o que provavelmente contribui para sua exist.ência em vegetação alterada, como é a da Reserva.
Apenas algumas espécies apresentam sua distribuição restrita a alguns estados brasileiros. É o caso de Vriesea gigantea, Philodendron propinquum, Eurystyles cotyledon e Notylia longispicata.

Em geral, as espécies não se distribuem por toda a área da Reserva. Esta apresenta heterogeneidade interna sob este aspecto. Algumas espécies são restritas às proximidades do riacho (Philodendron spp., Blechnum binervatum), provavelmente pela maior umidade do ar ali e talvez também por se tratar de uma área mais protegida da ação antrópica. Outras espécies só ocorrem em uma área muito bem definida dentro da Reserva (Vriesea gigantea, Tillandsia geminiflora, Polypodium aureum, $P$. triseriale), em melhor estado de conservação. A observação de uma árvore de pequeno porte, portadora de várias espécies de Orchidaceae, com vários indivíduos cada e uma só observada aí (Campylocentrum linearifolium), concorda com a grande especificidade que se acredita que essas plantas possuam.

Grande parte das epífitas presentes na Reserva também ocorre fora dela, nos seus arredores e sobre as árvores que compõem a arborização urbana de São Paulo. Isto vale principalmente para as espécies mais comuns $\mathrm{e}$ de distribuição mais ampla no interior da Reserva.

A análise das famílias presentes na Reserva e sua importância em termos de riqueza específica também pode levar a interpretações biogeográficas e ecológicas interessantes. Na grande maioria das floras epifíticas conhecidas, Orchidaceae é a família mais importante, seguida por Pteridophyta, Araceae ou Bromeliaceae. Este padrão se repete em áreas com pluviosidades as mais diversas (Dislich 1996).

No caso da flora da Reserva este padrão básico não é mantido. Aqui, o grupo com maior número de espécies é Pteridophyta, seguido por Bromeliaceae e Orchidaceae. O mesmo acontece no Parque Nacional El Rey, na Argentina. Brown (1990) relacionou a flora epifítica encontrada nas florestas montanas de El Rey com o fato de estas serem uma "ilha" biogeográfica em meio aos bosques xerófilos chaquenhos, com uma provável instabilidade devido a flutuações pleistocênicas nas condições climáticas. Por este motivo, a flora apresentaria poucos elementos próprios. Uma vez que as Pteridophyta e Bromeliaceae de El Rey ocorrem também nos bosques xerófilos, entende-se como elementos próprios as espécies de Orchidaceae.

Argumento análogo poderia ser usado para explicar a composição florística de epífitas na Reserva da CUASO. Grande parte das espécies ocorre também fora da Reserva, nos seus arredores, o que porém não acontece com as Orchidaceae, talvez pela especificidade de hábitat citada por Williams-Linera et al. (1995). Uma maior diversidade de orquídeas epífitas na área provavelmente não foi capaz de se manter em face da grande 
interferência humana, direta, através da derrubada de trechos da mata e coleta de plantas, ou indireta, através da poluição atmosférica, produzindo a composição florística incomum encontrada hoje na Reserva.

Por fim, é importante destacar a grande diversidade morfológica apresentada por este grupo de plantas. $\mathrm{Na}$ Reserva são encontrados representantes de todas as formas básicas de vida de epífitas discriminadas na litcratura (Benzing 1987, 1989ab, Kress 1989). As hemiepífitas primárias estão representadas pelas espécies de Ficus, estrangulantes, e por Philodendron bipinnatifidum, nào-estrangulante. Blechnum bivervatum e as outras espécies de Philodendron são hemiepífitas secundárias. As plantas restantes são holoepífitas, e se apresentam sob as formas mais diversas: pendentes, reptantes, eretas, grandes ou pequenas, com folhas em roseta ou não.

\section{Agradecimentos}

Os autores gostariam de expressar seus sinceros agradecimentos a todos aqueles que identificaram plantas ou colaboraram para que fossem identificadas: Fábio de Barros (IBt), Eduardo L. M. Catharino (IBt), Inês Cordeiro (IBt), João Vicente Coffani Nunes (USP), Jefferson Prado (IBt), Lúcia Rossi (IBt), Suzana L. Proença (IBt), Sérgio Romaniuc Neto (IBt), Cássia Mônica Sakuragui (USP), Nigel Taylor (Kew), e em especial a Elisabete A. Lopes (IBt). Também agradecemos às sugestões de dois assessores anônimos.

\section{Referências}

AGUIAR, L.W., CITADINI-ZANETTE V., MARTAU, L. \& BACKES, A. 1981. Composição florística de epífitos vasculares numa área localizada nos Municípios de Montenegro e Triunfo, Rio Grande clo Sul, Brasil. Iheringia, Bot. 28: 55-93.

BARROS, F. 1983. Flora Fanerogâmica da Reserva do Parque Estaclual das Fontes do Ipiranga (São Paulo, Brasil): 198-Orchidaceae. Hochmea 10: 74-124.

BARROS, F., MELO, M.M.R.F., CHIEA, S.A.C., KIRIZAWA, M., WANDERLEY, M.G.L. \& JUNG-MENDAÇOLLI, S.L. 1991. Caracterização geral da vegetação e listagem das espécies ocorrentes. In: Melo, M.M.R.F., Barros, F., Wanderley, M.G.L., Kirizawa, M., Jung-Mcndaçolli, S.L. \& Chiea, S.A.C. Flora Fanerogânica da Illa clo Carcloso, vol. 1. Instituto de Botânica. São Paulo.

BARROSO, G.M. 1962. Araceae do Brasil. Arq. Jard. Bot. Rio de Janciro 17:5-17.

BARTHLOTT, W. \& TAYLOR, N.P. 1995. Notes towards a Monograph of Rhipsaliclac (Cactaceae). Bradleya 13/1995: 43-79.

BENZINC, D.H. 1987. Vascular epiphytism: taxonomic participation and adaptive diversity. Ann. Missouni Bot. Gard. 74(2): 183-204.

BENZING, D.H. 1989a. Vascular epiphytism in America. In H. Lieth \& M.J.A. Werger (eds.) Tropical rainforest ecosystcms. Elsevier Science Publ. Co. New York, p. 133-154.

BENZING, D.IH. 1989b. The Evolution of Epiphytism. In U. Lüttge (ed.) Vascular Plants as Epiphytcs. Springer. Berlin, p. 15-41.

BENZING, D.I-I. 1990. Vascular epiphytes: general biology and related biota. Cambridge University Press. Cambridge.
BENZING, D.H. 1995. The physical mosaic and plant variety in forest canopies. Selbyana 16(2): 159-168.

BRANDĀO, C.R.F. 1980. Etogramas seqüenciais ao longo do desenvolvimento de Odontomachus affinis Guérin (Hymenoptera, Formicidae, Porinae). Dissertação de Mestrado. Instituto de Biociências, Universidade de São Paulo. São Paulo.

BRITTON, N.L. \& ROSE, J.N. 1963. The Cactaceae. vol. 3/4. Dover. New York.

BROWN, A.D. 1990. El epifitismo en las selvas montanas del Parque Nacional "El Rey", Argentina: Composición florística y patrón de distribución. Rev. Biol. Trop. 38(2a): 155-166.

BRUMMITT, R.K. \& POWELL, C.E. 1992. Authors of plant names. Royal Botanic Gardens. Kew.

BUDOWSKI, G. 1965. Distribution of tropical American rain forest species in the light of successional processes. Turrialba 15(1): 40-42.

CAMPOS, M.T.V.A. 1995. Composição florística e aspectos da estrutura e da dinâmica de três capões na Serra do Cipó, Minas Gerais, Brasil. Dissertação de Mestrado. Instituto de Biociências, Universidade de São Paulo. São Paulo.

CARAUTA, J.P.P. 1989. Ficus (Moraceae) no Brasil: conservação e taxonomia. Albertoa 2 (1): 1-365.

CERSÓSIMO, L.F. 1993. Variações espaciais e temporais no estabelecimento de plântulas em trecho de floresta secundária em São Paulo, $S P$. Dissertação de Mestrado.Instituto de Biociências, Universidade de São Paulo. São Paulo.

CERVI, A.C., ACRA, L.A., RODRIGUES, L., TRAIN, S., IVANCHECHEN, S.L. \& MOREIRA, A.L.O.R. 1988. Contribuição ao conhecimento das epífitas (exclusive Bromeliaceae) de uma floresta de araucária do primeiro planalto paranaense. Insula 18: 75-82.

CRONQUIST, A. 1981. An integrated system of classification of flowering plants. Columbia University Press. New York.

DE VUONO, Y.S. 1985. Fitossociologia do estrato arbóreo da floresta da Reserva do Instituto de Botânica (São Paulo - SP). Tese de Doutorado. Instituto de Biociências, Universidade de São Paulo. São Paulo.

DIAL, R. \& TOBIN, S.C. 1994. Description of arborist methods for forest canopy access and movement. Selbyana 15(2): 24-37.

DISLICH, R. 1996. Florística e estrutura do componente epifítico vascular na mata da reserva da Cidade Universitária "Armando de Salles Oliveira”, São Paulo, SP. Dissertação de Mestrado. Instituto de Biociências, Universidade de São Paulo. São Paulo.

DONAHUE, P.K. \& WOOD, T. M. 1995. A safe, flexible and noninjurious technique for climbing tall trees. Selbyana 16(2): 196200.

ENGLER, A. \& KRAUSE, K. 1913. Araceae - Philodendroideae Philodendreae. In A. Engler (ed.) Das Pflanzenreich. W. Engelmann. Leipzig, vol. 60, pt. IV.23Db, p. 1-143.

FERRI, M.G., MENEZES, N.L. \& MONTEIRO-SCANAVACCA, W.R. 1981. Glossário Ilustrado de Botânica. Nobel. São Paulo.

FONSÊCA, M.P. 1994. Aphyllophorales da Reserva Florestal Armando de Salles Oliveira, São Paulo, SP. Dissertação de Mestrado. Instituto de Biociências, Universidade de São Paulo. São Paulo.

GARCIA, R.J.F. 1995. Composição florística dos estratos aıbóreo e arbustivo cla mata do Parque Santo Dias (São Paulo - SP, Brasil). Dissertação de Mestrado. Instituto de Biociências, Universidade de São Paulo. São Paulo.

GENTRY, A.H. \& DODSON, C.H. 1987a. Diversity and Biogeography of Neotropical Vascular Epiphytes. Ann. Missouri Bot. Garclen 74(2): 205-233.

GENTRY, A.H. \& DODSON, C.H. 1987b. Contribution of nontrees to species richness of a tropical rainforest. Biotropica 19(2): $149-156$.

GOMES, E.P.C. 1992. Fitossociologia do componente arbóreo de un tre- 
cho de mata em São Paulo, SP. Dissertação de Mestrado. instituto de Biociências, Universidade de São Paulo. São Paulo.

GORRESIO-ROIZMAN, L. 1993. Fitossociologia e dinâmica do binco de sementes de populações arbóreas de floresta secunclária en São Paulo, SP. Dissertação de Mestrado. Instituto de Biociências, Universidade de São Paulo. São Paulo.

GRAF, A.B. 1992. Tropica-Color encyclopedia of exotic plants and trees. 4" ed. Roehrs. East Rutherford (NJ, EUA).

GRANDISOLI, E.A.C. 1997. Polinização, Biologia Repıodutiva e Estrutura cla população de Psychotria suterella Müell. Args. (Rubiaceac) cm uma Mata Secundária em São Paulo (SP). Dissertação de Mestrado. Instituto de Biociências, Universidade de São Paulo. São Paulo.

GuimarĩES, E.F. 1988. Flora Fanerogâinica da Reserva do Parque Estadual das Fontes do Ipiranga (São Paulo, Brasil): 10-Piperaceae. Hoehmea 15: 46-51.

GUIMARÃES, E.F., ICHASO, C.L.F. \& COSTA, C.G. 1984. Piperáceas: 4. Peperomia. Flora Ilustrada Catarinense (PIPE). Herbário Barbosa Rodrigues. Itajaí.

HARMS, H. 1898. Araliaceae. In A. Engler \& K. Prantl (eds.). Die natürlichen Pflanzenfanilien. Wilhelm Engelmamn. Leipzig, vol. 3 , pt. 8, p. 35-36.

HASUI, E. 1994. O papel das aves fiugívoras na dispersão cle sementes em um fiagmento de floresta estacional semidecídua secundária em Sĩo Paulo, SP. Dissertação de Mestrado. Instituto de Biociências, Universidade de São Paulo. São Paulo.

HERTEL, R.J.G. 1950. Contribuição à ecologia da flora epífita da Scrra do Mar (vertente oeste) do Paraná. Arq. Mus. Paranaense 8: 3-(3)3.

HOEINE, F.C. 1945. Flora Brasilica. Secretaria de Agricultura de São Paulo. São Paulo, vol. 12, pt. 2.

HOEHNE, F.C. 1949. Iconografia de Orchiclaceas do Brasil. F. Lanzara. S. Paulo.

HOFSTEDE, R.G.M.; WOLF, J.H.D. \& BENZING, D.H. 1993. Epiphytic biomass and nutrient status of a Colombian upper montane rain forest. Selbyana 14: 37-45.

JOLY, A.B. 1950. Estudo fitogeográfico dos campos do Butantã. Bol. Fac. Filos. Univ. São Paulo, Bot. 8: 5-68.

KELLY, D.L.; TANNER, E.V.J.; KAPOS, V.; DICKINSON, A.; GOODFRIEND, G.A. \& FAIRBAIRN, P. 1988. Jamaican limestone forests: floristics, structure and environment of three examples along a rainfall gradient. J. Trop. Ecol. 4: 121-156.

KNOBEL, M.G. 1995. Aspectos da regeneração natural do componente arbóreo-arbustivo de trecho da floresta da Reserva Biológica do Instituto de Botânica em São Paulo, SP. Dissertação de Mestrado. Instituto de Biociências, Universidade de São l'aulo. São Paulo.

KÖPPEN, W. 1948. Climatologia: con un estudio de los climas de la tierra. Fundo de Cultura Economica. Mexico.

KRÄNZLIN, F. 1922. Orchidaceae - Monandrae. Tribus Oncidiinae - Odontoglossae II. In A. Engler (ed.) Das Pflanzenreich. W. Engelmann. Leipzig, vol. 4, pt. 50, p. 113-114.

KRÄNZLIN, F. 1926. Monographie der Gattung Polystachya Hook. Fecles Repert. Spec. Nov. Regni Veg. Beil. 39: 74-75.

KRESS, W.J. 1989. The systematic distribution of vascular epiphytes. In U. Lüttge (ed.) Vascular Plants as Epiphytes. Springer. Berlin, p. $234-262$.

LAMAN, T.G. 1995. Safety recommendations for climbing rain forest trees with "single rope technique". Biotiopica 27(3): 406409 .

LELLINGER, D.B. 1988. Some new species of Campyloneurum and a provisional key to the species. Amer: Fern J. 78: 14-35.

LOMBARDI, J.A. 1991. O gênero Rhipsalis Gärtner (Cactaceae), no Estado de São Paulo. I. Espécies com ramos cilíndricos ou subcilíndricos. Acta Bot. Brasil. 5(2): 1991.
MAYO, S.J. 1991. A revision of Philodendion subgenus Meconostigma (Araceae). Kew Bull. 46(4): 601-682.

MEGURO, M., VINUEZA, G.N. \& DELITTI, W.B.C. 1979a. Ciclagem de nutrientes minerais na Mata Mesófila secundária I. Produção e decomposição de folhedo. Bol. Bot. Univ. São Paulo 7: 11-31.

MEGURO, M., VINUEZA, G.N. \& DELITTI, W.B.C. 1979b. Ciclagem de nutrientes minerais na Mata Mesófila Secundária II. O papel da precipitação na importação e transferência de Potássio e Fósforo. Bol. Bot. Univ. São Paulo 7: 61-67.

MEGURO, M., VINUEZA, G.N. \& DELITTI, W.B.C. 1980. Ciclagem de nutrientes minerais na Mata Mesófila Secundária III. Decomposição do material foliar e liberação de nutrientes minerais. Bol. Bot. Univ. São Paulo 8: 7-20.

MELHEM, T.S., GIULIETTI, A.M., FORERO, E., BARROSO, G.M., SILVESTRE, M.S.F., JUNG, S.L., MAKINO, H., MELO, M.M.R.F., CHIEA, S.C., WANDERLEY, M.G.L., KIRIZAWA, M. \& MUNIZ, C. 1981. Planejamento para elaboração da "Flora Fanerogâmica da Reserva do Parque Estadual das Fontes do Ipiranga (São Paulo - Brasil)". Hoehnea 9: 63-74.

NADKARNI, N.M. 1988. Tropical rainforest ecology from a canopy perspective. In F. Almeda \& C. M. Pringle (eds.) Tropical Rainforests: Diversity and Conservation. California Academy of Sciences and Pacific Division. American Association for the Advancement of Science. San Francisco.

OLIVEIRA, R.R. \& ZAÚ, A.S. 1995. Método alternativo de subida em árvore. Bromélia 2(1): 6-11.

PABST, G.F.H. \& DUNGS, F. 1977. Orchidaceae brasilienses. vol. 2. Brücke. Hildesheim.

PERRY, D.R. 1978. A method of access into the crowns of emergent and canopy trees. Biotropica 10: 155-157.

PERRY, D.R. 1984. The canopy of the tropical rainforest. Sci. Amer: 251: 138-146.

PERRY, D.R. 1991. A vida na copa da floresta. Ed. Interação. São Paulo.

PERRY, D.R. \& WILLIAMS, J. 1981. The tropical rain forest canopy: a method of providing total access. Biotropica 13: 283-285.

RADFORD, A.E., DICKISON, W.C., MASSEY, J.R. \& BELL, C.R. 1974. Vascular plant systematics. Harper \& Row. Nova York.

REITZ, R. 1957. Aráceas catarinenses. Sellowia 8: 20-70.

REITZ, R. 1983. Bromeliáceas e a malária-bromélia endêmica. In R. Reitz (ed.) Flora Ilustrada Catarinense (BROM). Herbário Barbosa Rodrigues. Itajaí.

ROMANIUC NETO, S. \& WANDERLEY, M.G.L. 1992. Flora Fanerogâmica da Reserva do Parque Estadual das Fontes do Ipiranga (São Paulo, Brasil): 19-Moraceae. Hoehnea 19(1/2): 165-170.

ROSSI, L. 1994. A flora arbóreo-arbustiva da mata da Reserva da Cidade Universitária "Armando de Salles Oliveira" (São Paulo, Brasil). Bol. Inst. Bot. (São Paulo) 9: 1-105.

SCHEINVAR, L. 1985. Cactáceas. Flora Ilustrada Catarinense (CACT). Herbário Barbosa Rodrigues. Itajaí.

SCILECHTER, R. 1915. Die Orchideen: ihre Beschreibung, Kultur und Züchtung. Paul Parey. Berlin.

SCHLECHTER, R. \& HOEHNE, F.C. 1926. Contribuição ao conhecimento das orchidaceas do Brasil III. Arch. Bot. São Paulo 1(3): $167-349$.

SEHNEM, A. 1968. Blecnáceas. In R. Reitz (ed.) Flora Ilustrada Catarinense (BLEC). Herbário Barbosa Rodrigues. Itajaí.

SEHNEM, A. 1970. Polipodiáceas. In R. Reitz (ed.) Flora Ilustrada Catarinense (POLI). Herbário Barbosa Rodrigues. Itajaí.

SMITH, L.B. \& DOWNS, R. J. 1977. Tillandsioideae (Bromeliaceae). Fl. Neotrop. Monogr: 14(2): 663-1492.

SMITH, L.B. \& DOWNS, R. J. 1979. Bromelioideae (Bromeliaceae). Fl. Neotrop. Monogr: 14(3): 1493-2142. 
SOTA, E.R. 1960. Polypodiaceae y Grammitidaceac argentinas. ()pra Lilloana 5: 1-9209.

TA1BARELLI, M. 1994. (Yaciras naturais e a dinânica sucessional de tum trecho de floresta na Serra da Cantareina, SP. Disserta(aio de Mestrado. Instituto de Biociências, Universidade de São l'aulo. Sĩo P’aulo.

TAMASHIRO, J.Y. \& 7ICKEL, C.S. 1991. Flora Fanerogâmica da Reserva do Parque Estadual das Fontes do Ipiranga (São Paulo, Brasil): 25-Cactaceac. Hoelnnca 18(2): 137-142.

TRY'()N, R.M. \& STOLZE, R.G. 1993. Ptericlophyta of Peru. Part V. 18. Aspleniaceae - 21. Polypodiaceae. Ficldiana, Bot. 32: 1-190.

TRYON, R.M. \& TRYON, A. 1982. Ferns and Allied Plants. Springer. New York.

USTERI, A. 1906. Contribuição para o conhecimento da flora dos arreclones da cidade de São Paulo. Annuario da Escola P'olytechmia cle Siño l'aulo (j: 85-102.

USTERI, A. 1911. Flora der Ungebung der Stadt São Paulo. Gustav Fisclere Jena.

VARANDA, E.M. 1977. Baliunço hídlico de espécies da Mata do Butanlii. Disscracão de Mestuado. Instituto de Biociências, Universidlucle de São Paulo. São l'aulo.

VEL()SO, H.P., RANGEL FILHO, A.L.R. \& LIMA, J.C.A. 1991.
Classificação da vegetạçoo brasileira, adaptada a um sistema universal. IBGE. Rio de Janeiro.

WAECIITER, J.L. 1986. Epífitos vasculares da mata paludosa do Faxinal, Torres, RS, Brasil. Iheringia, Bot. 34: 39-50.

WAECHTER, J.L. 1992. O epifitismo vascular na Planície Costeiral do Rio Grande do Sul. Tese de Doutoramento. Universidade Federal de São Carlos. São Carlos.

WANDERLEY, M.G.L. \& MOLLO, L. 1992. Bromeliaceae. In: M.M.R.F. Melo, F. Barros, M.G.L.Wanderlcy, M. Kirizawa, S.L. Jung-Mendaçolli \& S.A.C. Chiea (eds.) Flora Fancrogânica da Illha do Carcloso, vol. 3. Instituto de Botânica. São Paulo.

WHITACRE, D.F. 1981. Additional techniques and safety hints for climbing tall trees, and some equipment and information sources. Biotropica 13: 286-291.

WILCOX, B.A. \& MURPHY, D.D. 1985. Conservation strategy: the effects of fragmentation on extinction. Am. Nat. 125: 879887.

WILLIAMS-LINERA, G.; SOSA, V. \& PLATAS, T. 1995. The fate of epiphytic orchids after fragmentation of a Mexican cloud forest. Sellyyana 16(1): 3(3-40.

YUNCKER, T.G. 1974. The Piperaceae of Brazil III. Hoehnea 4: $71-413$. 